\title{
'Their Backs toward the Temple, and Their Faces toward the East:' The Temple and Toilet Practices in Rabbinic Palestine and Babylonia
}

\author{
Rachel Neis \\ University of Michigan \\ rneis@umich.edu
}

\begin{abstract}
This article treats the cultural meaning of rabbinic toilet rules from their Tannaitic instantiation through to later developments in Palestine and Mesopotamia. It argues that these rules draw their corporeal and mental bearings from the Jerusalem temple, in inverse and opposite directions to prayer deportment. It shows how the juxtaposition of the sacred (temple) and profane (toilet) triggered the temple in unlikely instances under the guise of prohibition. As such, toilet rules are the underside of a rabbinic mapping project, similar to rules of bodily orientation in prayer. This map, effectively drawn by corporeal direction and orientation, with the (absent) temple at its center, traversed Palestine and the Diaspora, and ignored contemporary religious and imperials maps and limes. Thus developing toilet practices can tell us something about how a minority religious and social formation shaped bodily functions not necessarily in the more predictable terms of disgust and expulsion but rather as devices through which to uphold a lost center.
\end{abstract}

\section{Keywords}

rabbis, temple, toilet, Jerusalem, sacred, body, prayer

My God, you go to the toilet and you sit on ideology! ${ }^{1}$

A worker at the Religious Council in Lod decorated a wall with pictures of rabbis without realizing that he would stop the disgusting habit of urinating

\footnotetext{
1) See the lecture presented by Slavoj Žižek, www.youtube.com/watch?v=FJ73hLQ64Ng at 3 minutes and 29 seconds. The written version in The Plague of Fantasies (New York: Verso, 1997), 5 is: "It is easy for an academic at a round table to claim that we live in a 
against the wall. A young resident of the city [said], "it's impossible to do it next to rabbis looking at you; even criminals give respect to rabbis. ${ }^{2}$

Žižek, like others before him, points out that there is nothing casual, obvious or universal, about that most every-day of human acts. For him toilet habits and design, which are often "occluded as 'utility," are actually the "externality which directly materializes ideology."3 For those such as Mary Douglas, practices framing excretion and urination need to be understood in terms of how cultures cope with "matter out of place" in the body, social and human. ${ }^{4}$ In this article I will attempt to understand the symbolic and cultural meaning of rabbinic toilet rules from their Tannaitic instantiation through to their later developments in Palestine and Mesopotamia. ${ }^{5}$ In so

post-ideological universe but the moment he visits the lavatory after the heated discussion, he is again knee-deep in ideology." Žižek claims that the German, French, and American (Anglo-Saxon) toilet designs which effectively display or conceal feces in varying ways, i.e., "the ideological perception of how the subject should relate to excrement" matches German "reflective thoroughness," French "revolutionary hastiness," and English "utilitarian pragmatism" (ibid.). These manifest politically in "German conservatism, French revolutionary radicalism, and English liberalism." Thanks to Minnie Sinha for this reference. Many thanks also to Ra'anan Boustan, Fritz Graf, Gil Klein, Jon Schofer, Aharon Shemes and Eibert Tigchelaar for comments on earlier versions of this article.

2) Yaffa Nevo, "It's like a Holy Wall. And It's Also Very Beautiful," n.p. [cited 22 November 2011]. Online: http://www.mynet.co.il/articles/0,7340,L-3762811,00.html.

3) Žižek, Plague, 4.

4) See Mary Douglas, Purity and Danger: An Analysis of Concepts of Pollution and Taboo (London: Routledge \& Kegan Paul, 1966), esp. 122; Douglas, Leviticus as Literature (Oxford: Oxford University Press, 1999), 178-80. Further works of Douglas on the body include Natural symbols; Explorations in Cosmology (1970; repr. New York: Pantheon, 1982); Implicit Meanings: Essays in Anthropology (London, Routledge \& Kegan Paul, 1975); In the Wilderness: The Doctrine of Defilement in the Book of Numbers (JSOTSup 158. Sheffield: JSOT Press, 1993); Collected Works (12 volumes; London: Routledge, 2003). However, see Sjaak van der Geest, "Not Knowing about Defecation," in On Knowing and Not Knowing in the Anthropology of Medicine (ed. Roland Littlewood; Walnut Creek, Calif.: Left Coast, 2007), 39-53 on the anthropological reluctance to talk about toilet, particularly defecation.

5) The significance of rabbinic toilet practice has thus far received its most in-depth treatment in Jonathan Wyn Schofer, Confronting Vulnerability: The Body and the Divine in Rabbinic Ethics (Chicago: University of Chicago Press, 2010). I do not focus on excrement or human waste matter itself, but rather on the rabbinic rules on bodily deportment when performing bodily functions. Other studies on Jewish toilet practice include Jacob Neusner, "The Religious Meaning of Bodily Excretions in Rabbinic Judaism: The Halakhah on Leviticus Chapter Fifteen-Zabim and Niddah," Approaches to Ancient Judaism, New Series 15 (1999): 177-240; Ari Z. Zivotofsky, "Your Camp Shall Be Holy": Halacha and 
doing my first step will be to show how the rabbis' toilet rules draw their corporeal, mental and affective bearings from the Jerusalem temple, in inverse and opposite directions to prayer deportment. I will argue that this juxtaposition of the sacred (temple) and profane (toilet) triggered the temple in the most unlikely of scenarios and places, allowing it to shape rabbinic bodily behavior, under the guise of prohibition.

I go on to trace the ways that the Yerushalmi and Bavli extended the geographical reach of these rules. I then show how bodily functions (via potential juxtaposition of the temple sacred) in these sources start to be thought of in terms of visibility and corresponding norms of concealment or modesty, terms and norms which themselves become objects of rabbinic knowledge and exposure. Finally, I argue that, inasmuch as these toilet rules correspond inversely to bodily orientation vis-à-vis the sacred (temple) in prayer, they are the underside of a rabbinic mapping project. This map, effectively drawn by corporeal direction and orientation and with the (absent) temple at its center, traversed Palestine and the Diaspora, and ignored contemporary maps and imperial limes laid down by Rome and Persia. Thus toilet practices can tell us something about how a particular religio-social formation (the rabbis) shaped bodily functions not necessarily in more predictable terms of disgust and expulsion but rather as devices through which to uphold a lost sacred center. ${ }^{6}$

\title{
Bodily Direction in Sacred Space: Contrast and Reverse Direction
}

\begin{abstract}
And there shall be an area for you outside the camp, where you may relieve yourself. With your gear you shall have a spike, and when you have squatted you shall dig a hole with it and go back and cover up your excrement. Since the Lord your God walks about in your camp to save you and to deliver your enemies to you, let your camp be holy; let him not see anything indecent ['ervat davar] among you and turn away from you. (Deut 23:13-15)
\end{abstract}

This set of biblical rules specifically concerns the geography of excretion and the disposal of waste matter in a war camp (Deut 23:10). Similar rules regulate the expulsion and purification of someone who has had a noctur-

Modern Plumbing," Journal of Halacha and Contemporary Society 29 (1995): 89-128; "Beth haKise," Encyclopedia Talmudica (Jerusalem: Yad Harav Herzog, 1992), 4:102-8.

6) Cf. Blake Leyerle, "Refuse, Filth, and Excrement in the Homilies of John Chrysostom," Journal of Late Antiquity 2 (2009): 337-56. 
nal emission (vv. 10-12). Qumran texts and Josephus' description of the Essenes suggest that some first-century Jews read these biblical rules beyond a war-camp scenario, in order to regulate all excretion. As we will see, in early rabbinic halakah there was a different and more restricted reading of these laws. Like some of the Dead Sea documents it considers the temple mount to be the "holy camp." However, rather than thinking about excretion (alone) and exclusion from the "holy camp," the Tannaim thought in terms of urination and defecation as well as corporeal orientation (whether within or without the "holy"). ${ }^{7}$

Mary Douglas's theory of the body as a microcosm of the social body and the management of its excretia as a way to order and establish social boundaries is perhaps borne out by these biblical and first century sources. However, it fails to explain what is at stake in later rabbinic conceptualizations of, and strategies for, urine and excrement. The rabbis manage these excretia by incorporation rather than by exclusion, disposal, and reintegration. That is to say, the strategy is to manage the movements and orientation of the body rather than to exclude it (or its secretions). ${ }^{8}$

In order to better see what was at stake in early rabbinic rules on bodily functions, we must first look at the map of the sacred that the rabbis drew, which is most vividly graphed in $t$. Ber. 3:15-16.

[A] Those standing outside the land should direct their hearts toward [mekavnin 'et libam keneged] the land of Israel, as it says...

[B] In the land of Israel they direct their hearts toward [mekavnin 'et libam keneged] Jerusalem and pray, as it says...

[C] Those standing in Jerusalem direct their hearts toward [mekavnin 'et libam keneged] the temple as it says...

[D] In the temple they direct their hearts toward [mekavnin 'et libam keneged] the chamber of the holy of holies and pray, as it says...

[E] Those standing in the north are found to have their faces to [pnehem l] the south, in the south their faces to [pnehem l] the north, in the east their faces to [pnehem $l$ ] the west, in the west their faces to [pnehem $l$ ] the east.

[F] All Israel is found to be to be praying toward one place.

\footnotetext{
7) Sifre 257-258, s.v. Deut 23:12-15 (Finkelstein 282). See t. Meg. 3:25. The Sifre minimizes the expulsion so that one has to leave the inner priestly area (in which the Shekhinah is said to reside) for the outer Israelite reaches of this putative camp (where one may relieve oneself). It also uses these laws to think about the kinds of behaviors (spitting etc.) deemed inappropriate for the Temple Mount.

8) Perhaps Bordieu's habitus provides a better analytic than Douglas's structural analysis.
} 
As I have argued elsewhere, body language, both facial and cardiac, is crucial to this map of concentric circles radiating from the focal point of the temple. This body language operates on both a literary level (i.e., moving from $\mathrm{B}$ to $\mathrm{F}$ ) and on a literal, physical level. The praying subject of the Tosefta trains his body on the temple. Or to put it differently, the temple effectively organizes and regiments bodies, faces and interior states.

The reverse directional effect is apparent in the laws of the same tractate of the Mishnah:

[A] A person should not behave light-headedly [yaqel rosho] while opposite [keneged] the eastern gate since it is directed toward [mekuvan keneged] the chamber of the holy of holies.

[B] He shall not enter the temple mount with his staff, his shoes, his wallet, with dusty feet, nor shall he use it as a shortcut; how much more so may he $[$ not $]$ spit there. ${ }^{9}$

The language in A resembles the directional language of the prayer instructions (see Table 1 below). A person must not behave frivolously while "opposite" or "toward" [keneged] the eastern gate," as this in turn (and here the directional language is doubled) is "directed opposite" [mekuvan keneged] the holy of holies." Here transmitted presences are conducted along directional axes. The temple's directional force shapes bodily and affective disposition in both ritual and prohibitive terms. A person directed opposite (i.e., eastwards of) the holy behaves decorously, even as the high priest must direct himself (or turn his face) in various ritual contexts, and praying subjects must direct their hearts and turn their faces. ${ }^{10}$

To see this, we might set m. Ber. 9:5, m. Ber. 4:5-6, and m. Ber. 5:1 side by side.

9) m. Ber. 9:5 (par. t. Ber. 6:19, Sifra Qedoshim 7:1 [Weiss 90d-91a], Sifre Deut 258 [Finkelstein 282]). The Mishnah and Tosefta's placement of these restrictions comes after a list of sight-triggered blessings and rules. I would argue that the thematic link of vision links these restrictions, which, after all, come into effect when one is directly facing the holy of holies.

10) See m. Midd. 2:4 for how terminology and geography of direction [kavanah, east] works in temple ritual. For hafikhat panim in the context of the high priest's approach to holy of holies on Yom Kippur see t. Yoma 2:11. 
Table 1

m. Ber. 9:5 [A] m. Ber. 4:5-6 [par. t. m. Ber. 5:1 Ber. 3:15-16]

A person should not be light-headed [qalut rosh]

while opposite [or toward, keneged] the eastern gate for he [or it] is

directed [or opposite, mekuvan] toward [keneged] the holy of holies. direct his heart [yekaven 'et libo] toward [keneged] the holy of holies.
One only stands to pray in a serious frame of mind [koved rosh].

The pious men of old would meditate for an hour and then pray, in order to

direct their heart to [sheyekavnu 'et libam l] "the place."

M. Ber. 5:1 addresses appropriate mental state and kavanah in inverse terms to those of $m$. Ber. 9:5. These contrasting mental states (gravitas or koved rosh versus light-headedness or qalut rosh) are juxtaposed with direction toward the sacred in locational terms (the holy of holies or "the place"). ${ }^{11}$ We can see how the holy of holies as a location and as a directional, directing and gravitational force was both a source of prohibition (as per m. Ber. 9:5) and an invitation or destination (as per m. Ber. 4:5-6 and t. Ber. 3:15-16).

This power of the temple over bodily deportment and direction is also apparent in two remarkable passages that the later rabbis would subsume under the prohibitions of $m$. Ber. 9:5. Both emphasize the geospatial (in reverse of prayer directions) as it pertains to bodily direction. We first treat m. Sukkah 5:5:

They arrived at the gate, which leads to the east.

They turned their faces [hafkhu'et panav] to the west and they said,

\footnotetext{
11) A person is directed opposite and thus behaves decorously-the effect is mental and affective, cast in terms of a gravitational pull toward the temple, literally "heavy head" (koved rosh) as opposed to "light head" (qalut rosh).
} 
Our ancestors were in this place, 'their back parts to the temple ['akhorehem lamiqdash] and their faces eastwards [panim qedmah], and they would prostrate themselves eastwards toward the sun' (Ezek 8:16);

But as for us, our eyes are toward God ['eyneynu le-yah].

Rabbi Judah said, "they repeated it saying, 'and we are to[wards] God and to[wards] God are our eyes."

M. Sukkah 5:5 is part of the rabbinic description of the ritual celebrations for the Sukkot pilgrimage festival in the Jerusalem temple. The priests make their way to the eastern gate "directly opposite the holy of holies" (m. Ber. 9:5). Whilst turning their faces [hafkhu'et panav], their "eyes toward God" and the sanctuary, as in proper prayer practice, they recall past "abominations" (Ezek 8:16). ${ }^{12}$ This particular ritual of facing, gazing and recitation, self-consciously casts itself in contrast to the idolatrous and blasphemous ritual of yore. Thus on a bodily level m. Sukkah 5:5 articulates a contrastive logic of attraction and concordance (turning the face, directing the heart or the eyes) toward the sacred versus inversion and discordance (turning the rear) of the body (and concomitant affect and attention) from the sacred.

The ritual of Ezek 8:16 is "abominable" on two counts: not only is sun worship idolatrous but also directing the rear to the sanctuary is blasphemous. ${ }^{13}$ It is not implausible that the "abomination" involved a ritual anasyrma, an actual exposure of the rear to the sanctuary. ${ }^{14}$ Such bodily exposures by priests in the context of the sacred are prohibited in the bible. ${ }^{15}$ The symbolics of turning one's back or rear upon the sacred was not lost on the rabbis, nor indeed would it have been lost on anyone living in the Near East. ${ }^{16}$ Neither was it lost on first-century Jews. Josephus relates that one Passover when Roman troops kept guard over crowds of pilgrims in the

12) For hafikhat panim in the context of seating arrangements see $t$. Sanh. 7:5.

13) See $2 \mathrm{Kgs}$ 10:27 for a description of Israelites desecrating a Baal temple by turning it into a latrine.

14) David Halperin, Seeking Ezekiel: Text and Psychology (University Park: Pennsylvania State University Press, 1993), 130-31. On anasyrma in Greek cultic ritual see Maurice Oldender, "Aspects of Baubo," in Before Sexuality: the Construction of Erotic Experience in the Ancient Greek World (ed. David M. Halperin, John J. Winkler, and Froma Zeitlin; Princeton, N.J.: Princeton University Press, 1990), 83-113.

15) Exod 20:26; 28:42.

16) b.Yoma 77a, b. Sukkah 53b and b. Qidd. 72b suggest that $m$. Sukkah 5:5 describes men exposing themselves and "defecating upwards (toward God) [klape ma'alab]." 
temple, a soldier pulled up his garments and exposed himself. Those Jews who saw this became enraged, declaring it a blasphemy directed not toward them but toward God himself. Unsurprisingly a riot ensued. ${ }^{17}$ The juxtaposition of sacred and profane, and the way it triggers aversion and discordance, surfaces in the contemporary news piece quoted at the start of this article. Here the presence of rabbinic portraits stopped locals from urinating against the wall of the Religious Council building. The portraits even endowed the wall with sanctity; the newspaper reports that locals dubbed the place a "holy wall."

T. Meg. 3:21-26, our second source, pursues a similar logic to m. Sukkah 5:5 and m. Ber. 9:5 in opposing the sacred with the profane in geospatial, orientational, terms.

[A] (21) How would the elders sit? Their faces were toward [pnehem klape] the people, and their backs toward ['akhorehen klape] the holy [qodesh]. When they carried the ark [tevah] its face [pneha] was toward the people, and its back toward the holy. When the priests raised their palms [to recite the priestly blessing], their faces were toward the people and their backs were toward the holy.

[B] The prayer leader of the synagogue, his face was toward the holy and all the people, their faces were toward the holy, as it says, "and the congregation assembled at the entrance of the tent of meeting (Lev 8:4)."

[C] (22) The entrance of a synagogue should only open eastwards, for we find that the entrance of the tabernacle [hekhal] opened east, as it says, $[\ldots]$

[D] (25) One who goes out to an optional war, goes back ${ }^{18}$ and squats, digs and covers, as it says, "You shall dig a hole with it and go back and cover up your excrement" (Deut 23:13).

[E] (26) One who eliminates [ha-mesikh 'et raglav], his face is toward [panav klape] the holy. ${ }^{19}$

One who urinates, his back is toward ['akhorav klape] the holy.

[F] Rabbi Yose said: to what does this refer? From Scopus and within, but from Scopus and beyond there is no need [for these restrictions]. ${ }^{20}$

\footnotetext{
17) Josephus, Ant. 20.108; War 2.224. The latter version describes the soldier exposing his rear (rather than his genitalia) to the crowd, then bending over, and emitting a sound. For a discussion of the two versions see Federico M. Colautti, Passover in the Works of Josephus (JSJSup 75; Leiden: Brill, 2002), 112.

18) Following Erfurt, hozer instead of Vienna's hofer.

19) See Lieberman, Tosefta Kifshuta, 5:1205; Tosefta, Lieberman ed., 2:360-61.

20) t. Meg. 3:26. MS Leiden has sofot.
} 
Here are a series of rules regarding the directions that various persons or objects (elders, priests, portable Ark, prayer leader, congregation) must face or turn their backs upon. The geographical and reverential point of reference is the "sacred," in other words the Jerusalem temple. ${ }^{21}$ The language is of bodily orientation, and the body language itself speaks to hierarchical and liturgical relations vis-à-vis the ultimate point of sanctity. Thus, certain embodiments of the sacred, such as the synagogue elders, are supposed to sit with "faces toward [pnehem klape] the people, and their backs toward ['akhorehem klape] the holy [qodesh] (A)." $22 \mathrm{D}$ transitions to the prosaic practices of toilet and invokes Deut 23:13 in the specific context of war. Given this, it breaks with the rest of in t. Meg. 3:21-26 in its strategy of separation rather than incorporation and orientation. $\mathrm{E}$ is of a piece with t. Meg. 3:21-26's general thinking through of sanctity and appropriate bodily positioning, using similar language of "facing" and turning the "back" (in this case the "rear") toward the sacred. It continues in the prosaic vein of $\mathrm{D}$, treating defecation and urination (separately). However, unlike A-C, and more like D, E thinks more in terms of contrastive values (profane versus holy) than in terms of relative sanctities.

The relationship between $\mathrm{D}$ and $\mathrm{E}$ is ambiguous at first blush. While they both share the topic of toilet practices, only $\mathrm{D}$ pertains to a war-camp setting. That $\mathrm{E}$ may not is signaled by its reference to the "holy" (i.e. the temple), the term used in the rest of $t$. Meg. 3:21-26. That E gestures toward the same reference point as the rest of the mishnah is reinforced by $\mathrm{R}$. Yose's statement in $\mathrm{F}$ which limits the force of $\mathrm{E}$ to only those areas within Scopus. ${ }^{23}$

21) This probably refers to Jerusalem (as tevah is already used to designate the ark). See Steven Fine, This Holy Place (Notre Dame, Ind.: University of Notre Dame Press, 1997), 30, 46, $72-73$ and references on 199, n. 125. See Lieberman, Tosefta Kifshuta, 5:11992005; Ginzberg, Commentary, 3:394.

22) Unit A lists three scenarios in which designated humans (and an object containing the Torah scroll) may have their rears to the sacred (i.e., the temple or Jerusalem), and which are thus face-to-face the folk of the Jewish congregation (presumably in a liturgical setting). By virtue of their status they seem to act as or mediate the sacred. Unit B by contrast has the prayer leader standing in the same direction as the congregants and with them facing toward the temple. C and D likewise speak to the themes of directional locus and reverential choreography, whether in terms of the synagogue's location or the respect due to an elder.

23) In the Dead Sea Scrolls the "camp" becomes equivalent to Jerusalem or to the Qumran settlement. Sifre Deut 258 uses Deut 23:15 "your camp shall be holy" as the basis for the rules of deference to the temple area (in $m$. Ber. 9:5B). Sifre Deut 257 considers that "you 
Effectively, the instructions in $t$. Meg. 3:26 (E) ensure that one directs the body so that the ensuing outcome whether solid or liquid is not directed toward the temple, with Rabbi Yose limiting the geospatial range of these rules. The content of toilet rules and the extent of their force seem to have been contested issues. Those at Qumran thought not in terms of bodily deportment, i.e., preventing offending body parts and emissions from facing the Jerusalem temple, but rather in terms of banning defecation completely from within certain limits of the holy city or camp. ${ }^{24}$ The rabbis allowed bodily functions to occur anywhere (even within the sacred city), but required care of the body when facing the sacred during prayer and bodily functions. ${ }^{25}$

Rabbi Yose, however, declares that these restrictive bodily directions need only be observed within the circumference of tsofim (Scopus). In

shall dig, and go back and cover your excrement" (Deut 23:14) as a basis for the rule that "a man ought not turn his flanks (motnav) southwards." This makes sense in the context of the temple geography envisioned in $m$. Ber. 9:5A. If a person's side faces south, then his front or rear will be facing the temple in the east. The Sifre then seems to be using the rules about the war camp as a basis for related (but not identical) temple related rules that dovetail with the orientational perspective of $m$. Ber. 9:5. The logic here is of analogy rather than equivalence.

24) The Essenes according to Josephus, War 2.147-149, went so far as to forbid evacuation on the Sabbath. Josephus describes how the Essenes went to private spots, dug trenches with hatchets, and defecated with their cloaks covering them "so that they may not offend the rays of the deity," (Thackeray, LCL) following which they covered the excrement. Sources at Qumran include 4QHalakha C (4Q472a), 11QTa 46:13-16, and 1QM 7:6-7. The latter two cite Deut 23:13-15 to recommend that toilets outside of the city of Jerusalem (11QTa 46:13-16) or camps (1QM 7:6-7) be arranged so that excrement not be "visible" at a distance of three (11QT $46: 13-16)$ or two (1QM 7:6-7) thousand cubits from city/camp. 11QTa 46:13-16 also does not allow the genitalia ( $\mathrm{yad}$ ) to be seen (which may also refer to posture and modesty while relieving oneself rather than directionality). 4QHalakha $\mathrm{C}$ may refer to the covering of excrement. There is a fairly copious scholarly literature on this, most of which is discussed and cited in Albert I. Baumgarten, "The Temple Scroll, Toilet Practices, and the Essenes," Jewish History 10.1 (1996): 9-20; Stephanie Harter-Lailheugue, "Toilet Practices among Members of the Dead Sea Scrolls Sect at Qumran (100 BCE-68CE)," RevQ 21/84 (2004): 579-84; and Jodi Magness, Stone and Dung, Oil and Spit: Jewish Daily Life in the Time of Jesus (Grand Rapids, Mich.: Eerdmans, 2011), 89-90; 108-11; 130-44.

25) It makes sense that those at Qumran would not make the Jerusalem temple the reference point of their bodily orientations whether in sublime or profane activities. The evidence is that those at Qumran prayed facing the sun, and consequently had their backs to the temple (cf. Ezek 8:16). See 4QDaily Prayers (4Q503) 33-35 ii 1-14 and on the Essenes, Josephus, War 2.128. 
Tannaitic literature, tsofim (Scopus), literally "viewers," was a halakic limit of the holy city, by which certain temple-related rites were to be conducted. ${ }^{26}$ Recalling t. Ber. 9:5, t. Pesah. 3:12 describes it as a place from which "one could see [ha-ro'e] [the temple] without anything intervening [mafsiq]." ${ }^{\prime 2}$

M. Ber. 9:5's logic of restricting one's behavior when within a certain range of the holy of holies, is rather vividly and most literally brought to life in the everyday of evacuation and micturition. T. Meg. 3: 21-26 combines the productive power of prohibition, with ostensibly 'positive' behaviors in order to define the limits of the sacred and the threshold of the profane. M. Ber. 9:5 does the same, particularly as it concerns spatialmental direction, attention and (dis) respect. This contrastive thinking, in which the limits, boundaries, and relative weights of the sacred are thought in juxtaposition with the profane, is frequently deployed in rabbinic literature. ${ }^{28}$ In this case, the intertwining of the deeply physical and highly symbolic registers of body language (facing or turning one's back or rear) toward the sacred is reinforced in the most bodily of articulations.

\section{Tannaitic Texts on Toilet and Temple}

One cannot understand the Tannaitic toilet rules without looking at the role of the temple in the rabbinic map of the sacred drawn through the geospatial manipulation of bodies. Just as the early rabbis made the temple and the holy of holies a facial and cardiac focus for praying bodies, so did they map the sacred by the positioning of bodies in toilet. From disallowing

26) For this see $m$. Pesah. 3:8 and t. Pesah. 3:12. For similar sight-based parameters in halakic determinations, see m. Roš Haš. 4: 2 and y. Roš Haš. 4:2, 18b-19a; m. Meg. 1:11-12; m. Zebah. 14:6. See Josephus, War 2.528; 5:67-68, 106-108 and Ant. 11:239 in which Josephus explains that Alexander met Jaddeus at Saphein which was called "'look-out' because both Jerusalem and the temple can be seen from there." There is a consensus that scopos and sofim (rabbinic and modern day) are one; see, e.g., Steve Mason, Flavius Josephus, Translation and Commentary (Leiden: Brill, 2000), 1:367; Lawrence Schiffman, Texts and Traditions: A Source Reader for the Study of Second Temple and Rabbinic Judaism (New York: KTAV, 1998), 131; Étienne Nodet, A Search for the Origins of Judaism: From Joshua to the Mishnah (JSOTSup 248; Sheffield: Sheffield Academic Press, 1997), 135 n. 20.

27) For laws that prescribe rituals of mourning (i.e. tearing the garment, reciting a biblical verse) when "one sees Jerusalem from șofim" see y. Mo'ed Qat. 3:7, 83b (par. b. Mo'ed Qat. 26a). For narratives about Tannaim that describe this, see Lam. Rab. 5:18 and b. Mak. 24b. 28) Examples in the Mishnah and Tosefta of Berakhot, in which prayer is contrasted to various bodily discharges, abound. See especially, m. Ber. 3 and t. Ber. 2, e.g., m. Ber. 3:4-5 and $t$. Ber. 2:16, 19. 
frivolity, to compelling bodies to turn this way or that whilst performing their basic functions, the holy of holies and the temple were inscribed in order to cast a shadow of awareness over rabbinic minds and bodies.

An issue that remains unaddressed in the Tannaitic toilet rules is their temporal reach. In other words what difference did the fact of the temple's material and functional absence make in the formation of these rules of respect to the temple vicinity and, consequently, to toilet-related rules? This question becomes even more acute in the later rabbinic sources which extend their geographical spread beyond tsofim and even beyond Palestine.

\section{Palestinian Toilet: Posture and Orientation}

In my treatment of the Tannaitic materials, I presented m. Ber. 9:5 (the injunction against frivolity in view of the holy of holies) in concert with t. Meg. 3:26 (directions for elimination and urination vis-à-vis the holy) and $m$. Sukkah 5:5..$^{29}$ This should not obscure the active role of the editor of the Yerushalmi, who, in the commentary on $m$. Ber. 9:5 immediately introduces a version of the rules in t. Meg. 3:26: ${ }^{30}$

[A] "A person should not act frivolously while opposite the eastern gates of the temple since it is directed toward the holy of holies. [m. Ber. 9:5]"

[B] It was taught: when he urinates, he should turn his face [hofekh panav] north. When he eliminates, he should turn his face [hofekh panav] south.

[C] R. Yose b. R. Abun said: about this it was taught: from Scopus and within.

[D] R. Akiva says: in any place but only a place in which there is no [intervening] wall.

[E] It was taught: one who eliminates should not put his face [yiten panav] to east-west but to the sides.

[F] R. Judah says: during the time of the temple.

[G] R. Yose says: from Scopus and within.

\footnotetext{
29) Sifre Deut 257-258 also gestures toward this link.

30) Y. Ber. 9:5, 14b-c. Cf. y. Ber. 4:5-6, 8b: [A] Said R. Jacob bar Aha, "It was taught there: one may turn [mahzirin] toward any direction except east [for the Prayer]." [B] Said R. Yose bar Abun, "Of old, 'their backs to the temple of the Lord and their faces toward the east, bowing to the sun toward the east' [Ezek 8:16]."
} 
[H] R. Akiva says: in any place and especially in a place where there is no intervening wall. $^{31}$

Not coincidentally, the Yerushalmi's use of language regarding facing and orientation while relieving oneself (hofekh panav klape-- he turns his face toward) precisely mirrors the language it uses for its version of the prayer directions in t. Ber. 3:15 (hofkhin 'et pnehen klape-they turn their faces toward). The difference is that the directions are reversed (B and E). Unlike t. Meg. 3:26, which only considered the direction of waste matter, the Yerushalmi also considers the potential exposure of private parts toward the temple. Thus while $t$. Meg. 3:26 had no trouble with recommending that men (the assumption is of a male anatomy) urinate with their backs toward the temple (so that the waste matter is directed away from it), the Yerushalmi requires that men face sideways when urinating (as per E) so as to be neither urinating toward the temple nor exposing the rear.

There are other significant differences and innovations in terms of order, substance and terminology in the Yerushalmi's assemblage of baraitot. ${ }^{32}$ One important element is the preservation of R. Yose's view in t. Meg. 3:26 limiting the operation of these rules to within a certain radius (from tsofim and within) of the temple area (C and $G)$. Another important element in the Yerushalmi is the insertion of R. Judah's teaching $(\mathrm{F})$, which injects a temporal limit to these rules. ${ }^{33}$ However, the Yerushalmi proceeds to effectively nullify such temporal and geospatial limits with the anecdotes

31) Note the changes in order, terminology and substance between this and t. Meg. 3:26. For example, the former uses cardinal directions (north, south) and the latter differentiates directions between "toward the people" and "toward the holy."

\begin{tabular}{|c|c|}
\hline t. Meg. 3:26 & y. Ber. 9:5, 14b-c \\
\hline $\begin{array}{l}\text { One who eliminates, his face is toward } \\
\text { [panav klape] the people/holy. }\end{array}$ & $\begin{array}{l}\text { It was taught: when he urinates, he should } \\
\text { turn his face [hofekh panav] north. }\end{array}$ \\
\hline $\begin{array}{l}\text { One who urinates, his back is toward } \\
\text { ['akhorah klape] the holy. }\end{array}$ & $\begin{array}{l}\text { When he eliminates, he should turn his } \\
\text { face [hofekh panav] south. }\end{array}$ \\
\hline Rabbi Yose said: to what does this refer? & R. Yose b. R. Abun said: about this it was \\
\hline From Scopus and within, but from Scopus & taught: from Scopus and within. [...] \\
\hline
\end{tabular}

32) I have also underlined all the portions of the Yerushalmi that represent changes or additional material.

33) Compare $y$. Ber. 4:5, $8 \mathrm{c}$ in which the same concern is raised with respect to the prayer directions. See above n. 30. There R. Abun establishes through exegesis that they apply behurbano. 
that follow, as well as with the addition of R. Akiva's statements (in D, H) who in contradiction to R. Yose would apply these rules everywhere.

What are the implications of these geospatial debates? The Yerushalmi's juxtaposition of $t$. Meg. 3:26 and m. Ber. 9:5 means that rather than the consideration in t. Meg. 3:26 concerning urination/defecation from any cardinal point vis-à-vis the temple, it is possible that we are now only considering such acts as performed to the east of the holy of holies (as per \#\#1, 2 and 3 in Fig. 1 below). ${ }^{34}$ On this reading B (\#1) and E (\#2) instruct one to face certain ways when relieving oneself when opposite the "holy of holies" - the difference between these two baraitot is that B differentiates directions based on the type of waste matter that ensues (liquid or solid) and $\mathrm{E}$ concerns only solid waste matter.

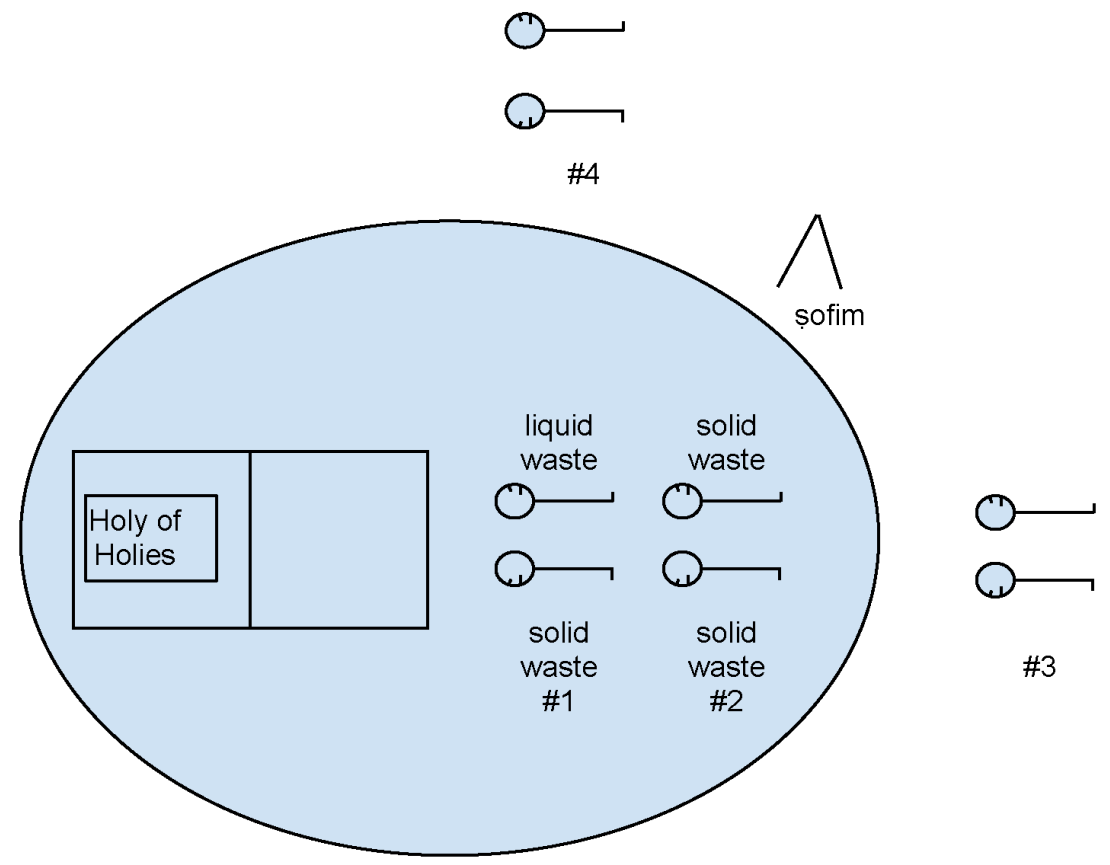

Figure 1. y. Ber. 9:5, 14b

34) It was only the view of R. Yose that limited the rules' application to within the circumference of Scopus and even his limitation could be understood as being anywhere along said circumference. 
In both sets of baraitot (B-D and E-H) the extent of this rule is debated. Rabbi Yose limits it to "Scopus and within" (C, G). Given the context of $m$. Ber. 9:5, which specifies "directly opposite" the holy of holies, I think it is fair to make a working assumption, that at least in the context of the Yerushalmi, we can read R. Yose as referring to a specific place from which Jerusalem is visible and which is directly opposite the holy of holies $(\# \# 1,2) .{ }^{35}$ It would seem that Rabbi Akiva's apparent disagreement in D and G ("in any place, as long as there is no wall") extends the force of the toilet postures/directions not only beyond this circumference but also to any point on it (i.e., not just in the east directly opposite the holy of holies, e.g., \#\#3 or 4$)$.

Perhaps the specificity of these disagreements seems petty, but their effects are not. By the time we get to Rabbi Akiva's radical extension of the geospatial applicability of these rules, we are engaged in a kind of thinking that encourages an exquisite awareness of bodily deployment in terms of a correspondingly heightened awareness of its impingement of the sacred. Whether facing this way or that, the body is thought of as potentially impinging on temple sanctity and so the temple effectively shapes bodily deportment, even from relatively far..$^{36}$ As with prayer, the gap between body and temple can be traversed and narrowed.

\section{Peeping Rabbis}

The two anecdotes that follow these debates about geospatial range and temporal reach, effectively overrule R. Judah's limitation of the rules to temple times, as they ostensibly provide empirical evidence that the force of these rules is ongoing.

[I] R. Akiva said: I entered after R. Joshua to see [lir'ot the deed.

They said to him: what did you see [raita]?

He said to them: I saw him [re'itiv] sitting with his side facing [klape] the west. He did not expose [pire'a] himself until he sat down. He did not sit

\footnotetext{
35) Two other possibilities are as follows: Scopus could be understood as a particular spot which is north-east on the range of mountains east of the temple that include the Mt. of Olives. Or it could have been understood as any place along this circumference, or any place from which Jerusalem was visible (as per t. Pesah. 3:12).

36) Through its logic, the Yerushalmi trains one to view the sacred as potentially ubiquitous, even intrusive, encouraging a hyper-sensitivity about the overlapping of the sacred with the profane.
} 
down until he had rubbed the place. And he did not wipe with his right hand, but with his left.

[J] Simon b. Azzai would say: I entered after R. Akiva to see [lir'ot] the deed. They said to him what did you see $\left[r^{\prime} i t a\right]$, etc.

Rabbi Akiva (D, G) extended the radial properties of the temple to encompass and circumscribe toilet postures. It is notable that the Palestinian storytellers then deploy him as a figure that investigates toilet practices first hand. Akiva forms a middle link in a chain of tradition, transmitting correct toilet postures and practices from R. Joshua to Ben Azzai. Through Akiva and Ben Azzai's eyes we learn the etiquette of which hand to use, which part of the body to turn away from the temple, and just as importantly to only minimally expose one's seat and genitalia. ${ }^{37}$ This is an important addition to the rules: even when one is directed properly so that the relevant bodily parts are turned away from the temple, one still has to minimize their visibility. This is no longer about the relationship of the profane to the sacred, it seems to be more about what we might recognize as modesty or privacy. However, we shall see, unlike the Bavli, this element is hardly brought out in as self-standing theme or concern.

The emphasis here on observation or re'iya (seeing) is apparent. Sight and knowledge are bound together. ${ }^{38}$ The theme of seeing in order to learn, and visibility in the face of the temple, are in some ways at odds with each other. The rabbinic protagonists Rabbi Joshua and Rabbi Akiva take care to hide their bodies, even as their students' eyes scan them for the knowledge that they might reveal. There is perhaps an irony that a teaching about not uncovering the body must be seen in order to be learned. As we will see, the Bavli makes much of, what is in the Yerushalmi, a more subtle and teasing possibility.

\footnotetext{
37) The side of his body therefore faces west - if he were to be east of the temple. However, this need not be relative to the temple. If one were to harmonize a reading of Rabbi Akiva $(D, G)$ with this anecdote, this would mean that one faces north/south regardless of where one is vis-à-vis the temple.

38) On the importance of sight for the transmission of rabbinic traditions, particularly in the Yerushalmi, see Martin S. Jaffee, Torah in the Mouth: Writing and Oral Tradition in Palestinian Judaism, 200 BCE-400 CE (New York: Oxford University Press, 2001), 150-54.
} 


\section{The Bavli: Temple and Toilet}

Both with respect to prayer and toilet, the Bavli thinks in the broadest of geographical terms. Consideration of toilet rules, especially in terms of vision and visibility, is drawn out at length in the Bavli's commentary on m. Ber. 9:5. ${ }^{39}$

[A] Rav Judah [BA2] said in the name of Rav [BA1]: they only said this with respect to tsofim and inward, and when one [it?] can see [ve-ro'e]. ${ }^{40}$

[B] It was also said: R. Abba the son of R. Hiyya b. Abba [PA3] said, so said R. Yohanan [PA2]: These rules apply only to Scopus and within and when he sees $\left[v e-r^{\prime} e\right]$ it, and when there is no fence, and at a time when the divine presence resides. ${ }^{41}$

[C] Our Rabbis taught: One who relieves oneself in Judea should not face [yifne] east and west but north and south. In Galilee he should face [yifne] only east and west.

[D] R. Yose, however, allows it, since R. Yose said: The prohibition was meant to apply when he sees [ve-ro'e] it and in a place where there is no fence intervening and at the time when the divine presence rests there. ${ }^{42}$

[E] The sages [in contrast with R. Yose] forbid it.

$[\mathrm{F}]$ The sages agree are in agreement with the first tanna [i.e., C]. They differ with regard to the sides. ${ }^{43}$

[G] It has been taught elsewhere: One who relieves oneself in Judea ${ }^{44}$ should not face [yifne] east and west but south and north, and in Galilee north and south is forbidden, east and west is permitted.

[H] R. Yose, however, permits it, since R. Yose used to say: This prohibition was meant to apply only when he sees [it].

39) B. Ber. 61b. See parallels in 'Abot R. Nat. 40 and Der. Er. Rab. 7:6. For an insightful analysis of elimination in these sources, see Schofer, Confronting Vulnerability, 53-76.

40) The verb ro' eh can have the person as its subject and the temple (or holy of holies) as its object. It is also possible (though perhaps less likely) that the temple is the subject of the verb and the object is the person.

41) Munich 95 has "when the temple is in existence."

42) Oxford Opp. Add. fol. 23 follows this with, "R. Benjamin said: even when he sees, at the time that the Shekhina resides, it is forbidden. When the Shekbina is not in residence, it is permitted." It continues with E, "And the sages say that either way, it is forbidden." Paris 671 has similar material, as does Oxford-Bodl. heb. b. 1 (2673) 1.

43) See Oxford Opp. Add. fol. 23 and Paris 671 for a complex distinction of the differences between the first Tanna and the sages and Rabbi that takes into account the differences between Judea and the Galilee. This is then related to the teachings of G.

44) Munich 95 has "one who relieves himself in any place" instead of "in Judea." 
[I] R. Judah says: When the temple is in existence it is forbidden; when the temple is not in existence it is permitted..$^{45}$

[J] R. Akiva forbids it in all places.

$[\mathrm{K}]$ R. Akiva is in agreement with the first tanna. They differ in the matter of outside of Palestine.

[L] Rabbah had bricks placed for him east and west. ${ }^{46}$ Abayye went and changed them round to north and south. Rabbah went in and readjusted them. He said, Who is this that is annoying me? I take the view of R. Akiva, who said that it is forbidden in every place.

[M] It has been taught: R. Akiva said: Once I went in after R. Joshua to a privy, and I learnt from him three things. I learnt that one does not sit east and west but north and south; I learnt that one evacuates not standing but sitting; and I learnt that it is proper to wipe with the left hand and not with the right. Said Ben Azzai to him: Did you dare to take such liberties with your master? He replied: This is Torah, and I must learn.

[N] It has been taught: Ben Azzai said: Once I went in after R. Akiva to a privy, and I learnt from him three things. I learnt that one does not evacuate east and west but north and south. I also learnt that one evacuates sitting and not standing. I also learnt it is proper to wipe with the left hand and not with the right. Said R. Judah to him: Did you dare to take such liberties with your master?-He replied: This is Torah, and I must learn.

[O] Rav Kahana once went in and hid under Rav's bed. He heard him chatting [with his wife] and joking and doing what he required. He said to him: One would think that Abba's mouth had never sipped the dish before! He said to him: Kahana, are you here? Go out, because it is proper conduct. He replied: This is Torah, and I must learn. ${ }^{47}$

This is a considerably more complex treatment of toilet postures vis-à-vis the temple than those we have examined heretofore-and it does not even end here. The Bavli expands greatly upon and differs significantly from earlier sources. ${ }^{48}$

45) Munich 95 has, "these rules apply only to Scopus and within and when one can see $\left[u-v e-r o^{\prime} e\right]$, and when there is no fence, and at a time when the divine presence resides."

46) Munich 95 has, "so that he would only evacuate north and south."

47) The text then goes on to explain why one wipes with the left hand and not the right. Oxford Opp. Add. fol. 23 and Paris 671, precede this with, "granted that one does not eliminate east and west out of respect for the Shekhina, and that one does not expose oneself while standing but rather while seated out of modesty but what is the reason one wipes..."

48) Beyond $\mathrm{O}$, the Bavli continues along the theme of posture, facing, toilet and temple in ways that are unparalleled in the Palestinian sources. 


\section{B. Ber. 61b, A-B}

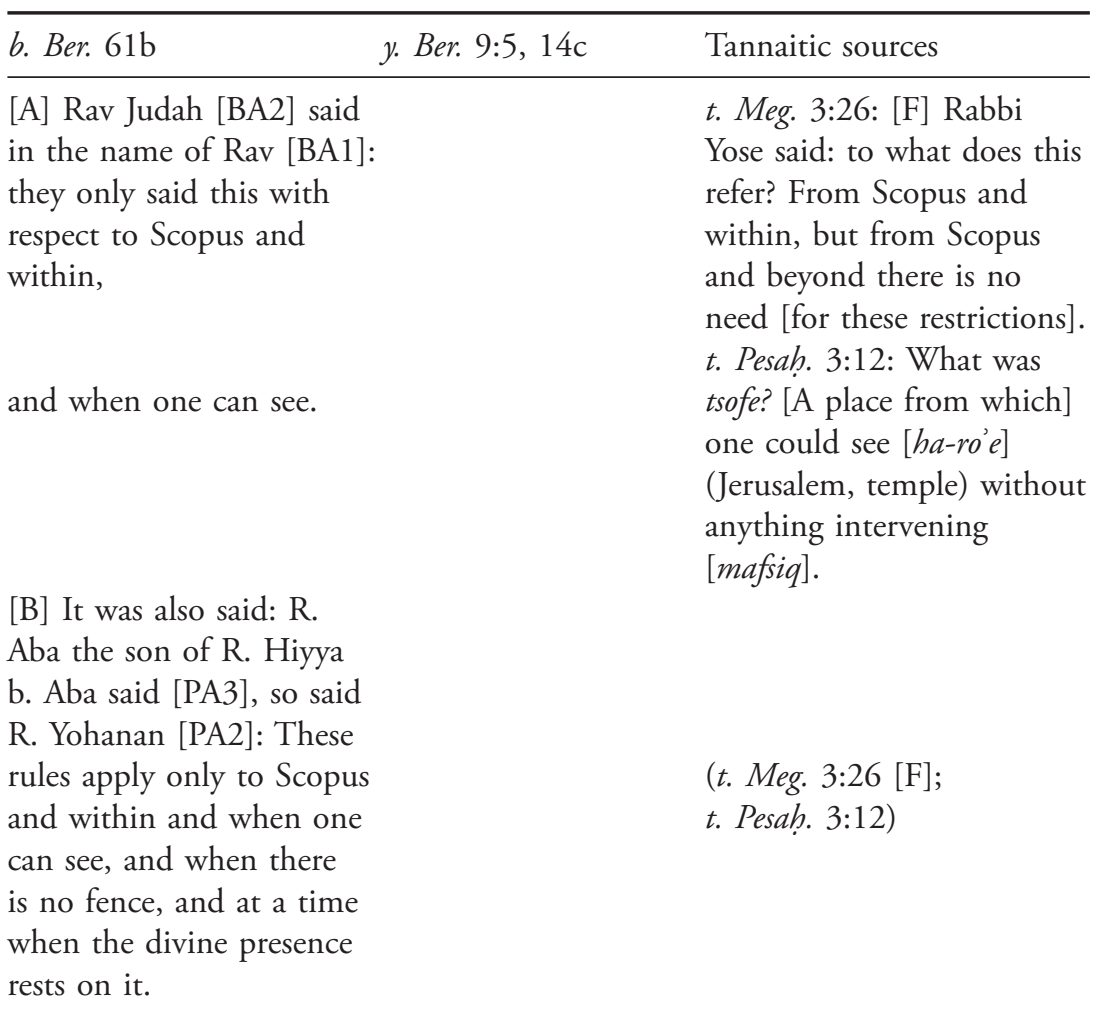

Unlike the Yerushalmi which immediately considered $m$. Ber. 9:5 in the context of toilet-related behavior, the Bavli first considers it in it broadest, unmarked context, which is simply about lightheadedness and inappropriate behavior. Furthermore, the Bavli in A-B works to limit the Mishnah's prohibition. ${ }^{49}$

49) In A, early Babylonian Amoraim weigh in to restrict the prohibition. Both of their limitations probably derive from the Mishnah's language of mekuvan keneged (directed opposite or directed toward). The editor also supplies B, a tradition in the name of R. Yohanan that adds more limitations. 


\section{B. Ber. 61b, C-D}

After the general determinations of the applicability of m. Ber. 9:5 in A-B, the Bavli moves to the rules on elimination (unlike the Yerushalmi and Tosefta it fails to consider urination):

\begin{tabular}{|c|c|c|}
\hline b. Ber. $61 \mathrm{~b}$ & y. Ber. 9:5, 14c & Tannaitic sources \\
\hline $\begin{array}{l}\text { [C] Our Rabbis taught: } \\
\text { One who eliminates } \\
\text { [ha-nifne] in Judea } \\
\text { should not face [yifne] } \\
\text { east and west but north } \\
\text { and south. In Galilee he } \\
\text { should only face [yifne] } \\
\text { east and west. }\end{array}$ & $\begin{array}{l}\text { [B] It was taught: one } \\
\text { who urinates [ha-metil } \\
\text { mayim] should turn } \\
\text { his face [hofekh panav] } \\
\text { north. } \\
\text { One who defecates } \\
{[\text { ha-mesikh 'et raglav] }} \\
\text { should turn his face } \\
\text { [hofekh panav] south. }\end{array}$ & $\begin{array}{l}\text { t. Meg. 3:26: [E] One } \\
\text { who eliminates } \\
\text { [ha-mesikh 'et raglav], } \\
\text { his face is toward } \\
\text { [panav klape] the holy. } \\
\text { One who urinates, } \\
\text { his back is toward } \\
\text { [akhorav klape] the } \\
\text { holy. }\end{array}$ \\
\hline $\begin{array}{l}{[\mathrm{D}] \text { R. Yose, however, }} \\
\text { allows it, since R. Yose } \\
\text { said: They only } \\
\text { prohibited when one sees } \\
{\left[v_{e-r o} e\right][\mathrm{it}] \text {; in a place }} \\
\text { where there is no fence } \\
\text { [geder]; and at the time } \\
\text { when the divine presence } \\
\text { rests there. }\end{array}$ & $\begin{array}{l}\text { [C] R. Yose b. R. Abun } \\
\text { said: about this it was } \\
\text { taught: from Scopus and } \\
\text { within. } \\
\text { [D] R. Akiva says: in any } \\
\text { place but only a place in } \\
\text { which there is no [inter- } \\
\text { vening] wall. }\end{array}$ & $\begin{array}{l}\text { t. Meg. 3:26: }[\mathrm{F}] \text { Rabbi } \\
\text { Yose said: to what does } \\
\text { this refer? From Scopus } \\
\text { and within, but from } \\
\text { Scopus and beyond } \\
\text { there is no need [for } \\
\text { these restrictions] } \\
\text { t. Pes. 3:12. }\end{array}$ \\
\hline
\end{tabular}

We are immediately struck by how the Bavli (in the form of a baraita, to be sure) introduces rather broad geographical considerations into the choreography of defecation. It distinguishes between Judea (in the region of the temple, Jerusalem and south thereof) and Galilee (north thereof). Note that tsofim no longer features here as a potential limit boundary on temple-impinged-behavior and bodily comportment, though it is hinted at by the vision requirement $\left(v e-r o^{\prime} e\right)$. The temple delineates behavior well beyond the confines of Jerusalem. ${ }^{51}$

\footnotetext{
50) Biblical examples of this expression for defecation include 1 Sam 24:3 and Judg 3:24.

51) The Bavli only features Scopus as a limit or boundary for lightheadedness in A and B. Even though it is not a limit for the purposes of elimination, R. Yose's requirement that one see the temple in $\mathrm{D}$ and $\mathrm{H}$ rather restricts the reach of these rules.
} 


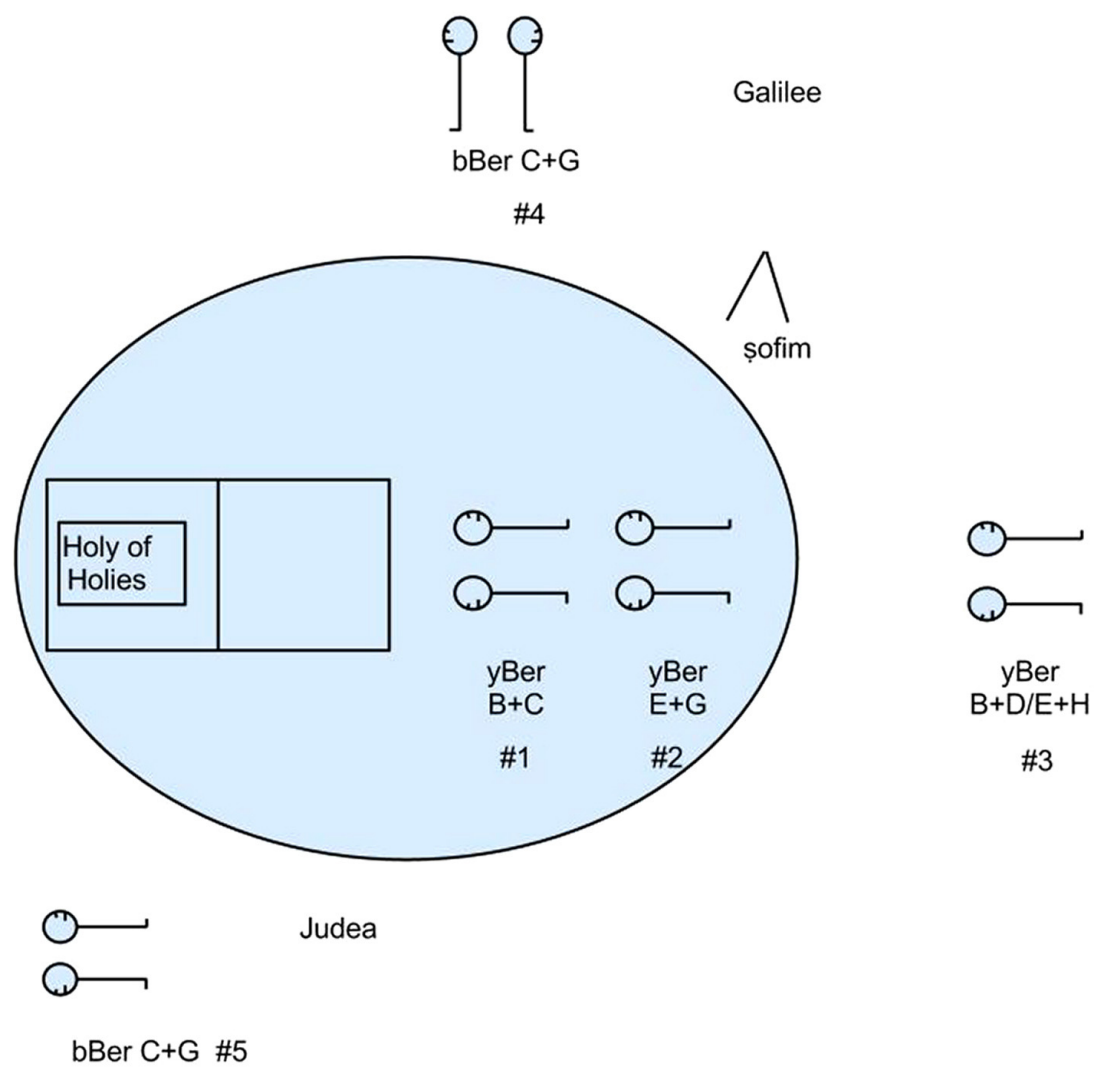

Figure 2

We might have thought that the bodily choreography itself would be relative to the location of the temple, and perhaps more specifically to that of the holy of holies (given m. Ber. 9:5). However, the directions proposed in the Bavli are static rather than relative to the temple. For example, we might think that someone relieving himself in parts of Judea that are south (rather than east) of the temple ought to have faced neither north nor south but only east-west, thus ensuring that neither his front nor back face the temple. In spite of this, the injunction is that "one who eliminates [ $h a-$ nifne] in Judea should not face [yifne] east and west but north and south" (as per \#5 in Fig. 2)..$^{5}$

52) This comports with the views of R. Joshua b. Levi and Rabbi Abbahu in b. B. Bat. 25a that "the Shekhina is in the west." Schofer, Confronting Vulnerability, 62, puts it most 
In t. Meg. 3:26 and y. Ber. 9:5, 14c Rabbi Yose limited the force of directional rules to "tsofim and within." However, in the parallel instance in the Bavli, the rules at hand already pertain to beyond Jerusalem (i.e., to the Galilee and Judea) and so Rabbi Yose's disagreement (D) is transformed into one that straightforwardly disputes the application of these rules to these extended areas and times. ${ }^{53}$

\section{B. Ber $61 b$ E-F}

An additional innovation of the Bavli is the introduction of the view of apparently later Tannaim in E, who like the "first tanna" at C, also uphold these rules:

\begin{tabular}{|c|c|c|}
\hline b. Ber. $61 \mathrm{~b}$ & y. Ber. 9:5, 14c & Tannaitic Sources \\
\hline $\begin{array}{l}{[\mathrm{E}] \text { The Sages, }} \\
\text { however, forbid it. }\end{array}$ & $\begin{array}{l}\text { [D] R. Akiva says: in any } \\
\text { place but only a place } \\
\text { in which there is no } \\
\text { [intervening] wall [ kotel]. }\end{array}$ & $\begin{array}{l}\text { t. Pes. 3:12: What was } \\
\text { tsofe? [A place from } \\
\text { which] one could see } \\
\text { [ha-ro'e] (Jerusalem, } \\
\text { temple) without anything } \\
\text { intervening [mafsiq]. }\end{array}$ \\
\hline $\begin{array}{l}{[\mathrm{F}] \text { The Sages say the }} \\
\text { same as the first tanna? } \\
\text { They differ with regard } \\
\text { to the sides. }\end{array}$ & & \\
\hline
\end{tabular}

clearly: "Should one avoid exposure in the direction of the temple, or alignment with its east-west axis?"

53) The particulars of the formulation in $D$ combine elements of the definition of Scopus in t. Pesah. 3:12, as well as y. Ber. 9:5, 14c D, in which Rabbi Akiva limits the rules' application to when no wall intervenes. The temporal limit of D echoes that of R. Judah. See $y$. Ber. 9:5, 14c at $\mathrm{F}$ and $b$. Ber. $61 \mathrm{~b}$ at I. The same can be said for the view attributed to Rabbi Yohanan in the Bavli at B. It mirrors the Bavli's version of R. Yose, except that R. Yohanan adds the specification of Scopus. 
In a typical move, the anonymous editor asks if there is any difference between the views of the earlier and later sages (i.e., between $\mathrm{C}$ and $\mathrm{E}$ ). $\mathrm{He}$ answers that they disagree with respect to the issue of the "sides" [tsedadin]. While the term is used in $y$. Ber. 9:5, 14c E to designate the sides of the body (as opposed to the face or rear), this does not seem to be the sense intended here. In keeping with Rashi, this disagreement concerns someone who is in a spot in Judea or Galilee that is not in line with, or opposite, the temple. The first tanna would say the rules still pertain; the later sages that they do not. In keeping with this interpretation, while the later sages do not agree with $\mathrm{R}$. Yose that the temple must be visible, they do require some kind of geographic correspondence. One needs to be on the same axis as the temple. According to this third view, a person could be quite far away from the temple, not see it, or be behind an intervening wall, but still have to conform to its presence in his toilet behaviors, as if it were "directly opposite" him. Even the view of the later sages allows the temple to travel quite far.

\section{B. Ber. $61 \mathrm{~b} \mathrm{G-K}$}

In $\mathrm{G}$ we find a second version of the positional rules (which are effectively the same as $\mathrm{C}$ ) but with a slightly different range of disputing views following. Rabbi Yose here is said to simply limit the prescriptions to situations in which one sees the temple $(\mathrm{H})$. (See Table below.)

Rabbi Judah in I limits the rule's applicability to temple times (as in $y$. Ber. 9:5, 14c, F), and Rabbi Akiva in J extends the rule to "all places." In the Yerushalmi, Rabbi Akiva declares "from any place as long as there is no intervening wall." However, the Bavli shears the second qualification from its record so ensuring his pronouncement's broader application. The innovation that most betrays the interest and location of the anonymous editor is that in K. Here Rabbi Akiva is said to differ with the first opinion in G only with respect to the application of the rule outside of Palestine. As such, the first opinion is construed to pertain only to the land of Israel (hence it enumerates "Judea" and "Galilee") whereas Rabbi Akiva also includes the Diaspora (hence "any place.") It is the anonymous editorial voice that construes or constructs the debate as such, so ensuring that Rabbi Akiva extends the reach of these rules to the Diaspora-and consequently to Babylonia itself. 


\begin{tabular}{|c|c|c|}
\hline b. Ber. $61 \mathrm{~b}$ & y. Ber. 9:5, $14 \mathrm{c}$ & Tannaitic Sources \\
\hline $\begin{array}{l}\text { [G] It has been taught } \\
\text { elsewhere: One who } \\
\text { eliminates in Judea } \\
\text { should not face [yifne] } \\
\text { east and west but south } \\
\text { and north, and in Galilee } \\
\text { north and south is } \\
\text { forbidden, east and west } \\
\text { is permitted. }\end{array}$ & $\begin{array}{l}\text { [E] It was taught: one } \\
\text { who eliminates should } \\
\text { not put his face [yiten } \\
\text { panav] to east-west but } \\
\text { to the sides. } \\
\text { [F] R. Judah says: during } \\
\text { the time of the temple. }\end{array}$ & t. Meg. 3:26: [E] \\
\hline $\begin{array}{l}{[\mathrm{H}] \text { R. Yose, however, }} \\
\text { permits it, since R. } \\
\text { Yose used to say: This } \\
\text { prohibition was meant } \\
\text { to apply only when he } \\
\text { sees [it]. }\end{array}$ & $\begin{array}{l}{[G] \text { R. Yose says: from }} \\
\text { Scopus and within. }\end{array}$ & $\begin{array}{l}\text { t. Meg. 3:26: [F] } \\
\text { t. Pes. 3:12: What was } \\
\text { tsofe? [A place from } \\
\text { which] one could see } \\
\text { [ha-ro'e] [Jerusalem, } \\
\text { temple] without } \\
\text { anything intervening } \\
\text { [mafsiq]. }\end{array}$ \\
\hline \multicolumn{3}{|l|}{$\begin{array}{l}\text { [I] R. Judah says: When } \\
\text { the temple is in existence } \\
\text { it is forbidden, when the } \\
\text { temple is not in existence } \\
\text { it is permitted. }\end{array}$} \\
\hline $\begin{array}{l}{[\mathrm{J}] \text { R. Akiva forbids it in }} \\
\text { all places. }\end{array}$ & $\begin{array}{l}{[\mathrm{H}] \mathrm{R} \text {. Akiva says: }} \\
\text { in any place and in a } \\
\text { place where there is no } \\
\text { intervening wall. }\end{array}$ & \\
\hline $\begin{array}{l}{[\mathrm{K}] \text { R. Akiva says the }} \\
\text { same as the first tanna. } \\
\text { They differ in the matter } \\
\text { of outside of Palestine. }\end{array}$ & & \\
\hline
\end{tabular}




\section{B. Ber. $61 b$ L-O}

It is at this point that a quartet of anecdotes is placed (in contrast to the Yerushalmi's duet)..$^{54}$ The Yerushalmi's two anecdotes are embellished and sandwiched in between two anecdotes featuring Babylonian Amoraim.

b. Ber. $61 \mathrm{~b}-62 \mathrm{a}$

y. Ber. 9:5, $14 \mathrm{c}$

[L] Rabbah [BA3] had bricks placed for him east and west. Abayye [BA4] went and changed them round to north and south.

Rabbah went in and changed them. He said, Who is this that is troubling me? I take the view of R. Akiva, who said that it is forbidden in every place.

[M] It has been taught:

R. Akiva [T2/3] said: Once I went in after R. Joshua to a privy, and I learnt three things from him. I learnt that one does not evacuate [nifnin] east and west but north and south;

[I] R. Akiva said: I entered after R. Joshua to see [lir'ot] the deed. They said to him: what did you see [raita]?

He said to them: I saw him [reitiv] sitting with his side [tsido] facing [klape] the west.

54) For analyses of these anecdotes see Daniel Boyarin, Carnal Israel: Reading Sex in Talmudic Culture (Berkeley: University of California Press, 1993), 122-25; Yaakov Elman, "Torah ve-Avodah: Prayer and Torah Study as Competing Values," in Jewish Spirituality and Divine Law (ed. Adam Mintz and Lawrence Schiffman; New York: KTAV, 2005), 61-124 (on the relationship between $b$. Ber. 62b and $y$. Ber. 9:5, 14c); Jeffrey L. Rubenstein, Stories of the Babylonian Talmud (Baltimore: Johns Hopkins University Press, 2010), 212-14; Shamma Friedman, "A Good Story Deserves Retelling: the Unfolding of the Akiva Legend," in Creation and Composition: The Contribution of the Bavli Redactors (Stammaim) to the Aggada (TSAJ 114; ed. J. Rubenstein; Tübingen; Mohr Siebeck, 2005), 71-100; idem, "The Further Adventures of Rav Kahana: Between Babylonia and Palestine," in The Talmud Yerushalmi and Graeco-Roman Culture III (TSAJ 93; ed. Peter Schäfer; Tübingen; Mohr Siebeck, 2002), 247-71. 
(cont.)

b. Ber. $61 \mathrm{~b}-62 \mathrm{a}$

y. Ber. 9:5, $14 \mathrm{c}$

I learnt that one evacuates not standing but sitting;

He did not expose [ pire $\left.^{\prime} a\right]$ himself until he sat down. He did not sit down until he had rubbed the place.

and I learnt that it is proper to wipe with the left hand and not with the And he did not wipe with his right right. hand, but with his left.

Said Ben Azzai [T3] to him: Are you so brazenfaced with your master? He replied: This is Torah, and I must learn.

[N] It has been taught:

Ben Azzai said: Once I went in after R. Akiva to a privy,

[J] So Simon b. Azzai would say: and I learnt from him three things. I learnt that one does not evacuate east and west but north and south. I entered after R. Akiva to see [lir'ot] the deed. They said to him what did you see $\left[r a^{\prime} i t a\right]$, etc. I also learnt that one evacuates sitting and not standing. I also learnt it is proper to wipe with the left hand and not with the right.

Said R. Judah [T3] to him: Are you so brazenfaced with your master?-He replied: This is Torah, and I must learn.

[O] Rav Kahana once went in and hid under Rab's bed.

He heard him chatting [with his wife] and joking and doing what he required.

He said: Abba's mouth is like one that has not swallowed food. 
(cont.)

b. Ber. $61 \mathrm{~b}-62 \mathrm{a}$

y. Ber. 9:5, 14c

He said to him: Kahana, are you

here? Go out, because it is not

proper conduct.

He replied: This is Torah, and

I must learn. ${ }^{55}$

The first anecdote transitions from Akiva's statement in $\mathrm{K}$ by having its protagonist Rabbah cite Rabbi Akiva as the source for his practice. It also concretizes the Diasporic extension in K, i.e., "outside of Palestine." Rabbah's practice was to have bricks placed along the east and west of his toilet to guide his bodily orientation. There are two ways to understand this practice: one is that this reminded him which sides were "directed opposite" the temple, with Rabbah keeping them parallel to the sides of his body. The other is that the bricks functioned as barriers (admittedly following the Akivan tradition of the Yerushalmi) thus blocking his front or back from facing the temple should they be turned toward it (as per R. Yose's ve-ro'e in H). ${ }^{56}$

The story demonstrates how far (literally and metaphorically) a Babylonian sage, Rabbah, took the toilet rules. ${ }^{57} \mathrm{He}$ understands that but for this obstruction or orientation he would be considered to be relieving himself while facing the temple. Rabbah enacts Rabbi Akiva's view, just as he invokes him in his anger at Abayye's intervention. The narrative uses humor with the practical joking of Abayye who deliberately changes the bricks around, making the reader uncertain as to whether Rabbah is to be regarded as an exemplary figure, or as a figure of fun. Here and in the anecdote in $\mathrm{O}$, the comical aspects of the Joshua b. Levi-Akiva-Ben Azzai narratives are enhanced, as rabbis follow their masters, not just into toilets but also into their conjugal beds (with the story of Rav Kahana and Rav in O).$^{58}$

\footnotetext{
55) Par. b. Hag. 5b.

56) Or perhaps they blocked him from being seen, given the Bavli's emphasis on modesty.

57) Babylonia is east of the temple. Here the Talmud brings us back to a place that is theoretically "facing opposite the holy of holies."

58) The justification of all three peeping rabbis is that "this is Torah and I must learn." Thusly the Bavli thematizes the potential critique of (and vindicates) its own project in detailing the ins and outs (as it were) of rabbinic bodies.
} 
Both Babylonian and Palestinian versions of this narrative doublet use the heavy-handed device of Rabbi Akiva as a link in the chain of Torah transmission: first as peeping-Tom protagonist, and then himself as the object of Torah observation. A significant Babylonian embellishment is the insertion of Ben Azzai and R. Judah as interlocutors who explicitly challenge the behaviors of Rabbi Akiva and Ben Azzai. They question the "brazen-facedness" of Rabbi Akiva and Ben Azzai respectively. This also has the effect of setting up Ben Azzai as an additional link between the two stories. ${ }^{59}$ The challenge itself is significantly different from the Yerushalmi's anonymous and more neutral inquiry of "what did you see." Instead of soliciting evidence, the Bavli's question expresses the potential critique (and paradox) of its own project of detailing the ins and outs of rabbinic bodily functions. The answer to these questions then allows the Bavli to justify this project in terms of acquisition of Torah knowledge. ${ }^{60}$ The challenge also alerts us to a particularly Babylonian sensitivity about modesty and privacy, which is reinforced by the deliberations that follow these stories. ${ }^{61}$ That this is an aspect of a peculiarly Babylonian sensibility is also reinforced by the way these two stories $(\mathrm{M}-\mathrm{N})$ are sandwiched in between the Babylonian location and protagonists of $\mathrm{L}$ and $\mathrm{O} .{ }^{62}$

As we will see, sources, rabbinic and otherwise, suggest Babylonian Jewish exposure to a Persian culture of modesty surrounding bodily functions. ${ }^{63}$ Stories in $b$. Ber. 62a-b manifest a concern about the propriety of relieving oneself when someone else is present which would probably not

\footnotetext{
59) In the Yerushalmi anonymous interlocutors ask the rabbis "what did you see."

60) Furthermore, the language of learning is emphasized [l.m.d. appears five times] over the Yerushalmi's emphasis on vision [r'.h. appears three times]. Where the Yerushalmi uses sight as a signal that authenticates the transmitted knowledge, the Bavli with its repeated claims of "this is Torah and I must learn," structurally reinforces a mimetic toilet tradition transmitted through four generations of rabbis (from Joshua b. Levi to Judah). The technologies of vision and proximity collaborate to ensure that not only the vigilant viewpoint of the temple regulates, but also empowers the knowledge-thirsty gaze of the student to survey and spectate in relatively private spaces.

61) B. Ber. 61b.

62) Both $\mathrm{L}$ and $\mathrm{O}$ are in Aramaic with the exception of Rav Kahana's response of "this is Torah and I must learn" (which is in Hebrew), as opposed to $\mathrm{M}$ and $\mathrm{N}$ which are in Hebrew.

63) Other ways in which the sacred and the profane are juxtaposed include sex near a Torah scroll (b. Ber. 25a); Shema' and 'ervah (y. Hal. 2:4, 58c; b. Ber. 24a) and tefillin and nudity (t. Ber. 2:20; y. Ber. 2:3, 4c; b. Ber. 25a).
} 
have been recognizable to Palestinian rabbis familiar as they were with (Roman) public latrines. ${ }^{64} \mathrm{We}$ noted that conflict between modesty and knowledge in the tales of the peeping rabbis is not visible in the parallel Yerushalmi.

An ethnographically styled observation, found earlier in the tractate of Berakhot, links modesty to the Persians in the following way:

For three things I like the Persians, They are modest when they eat, they are modest in the toilet, and they are modest in another matter $[\mathrm{sex}]{ }^{65}$

Despite its Palestinian Tannaitic tradent, this tradition says more about Babylonian rabbinic awareness of Persian toilet etiquette. A variety of sources from Xenophon (fourth c. B.C.E.) and Herodotus (fifth c. B.C.E.) to Amanianus Marcellinus (fourth c. C.E.) confirm this perception of Persians as unusually modest in their toilet practices. ${ }^{66}$ Zoroastrian sources

64) For studies on Roman sanitation and latrines, see Ann Olga Koloski-Ostrow, Gemma C. M. Jansen, and Eric M. Moormann, ed., Roman Toilets: Their Archaeology and Cultural History (Leuven: Peeters, 2011). For a general history see David Inglis, A Sociological History of Excretory Experience: Defecatory Manners and Toiletry Technologies (Lewiston, N.Y.: Edwin Mellen, 2001). On changing standards of privacy and modesty, including their tightening in late antique Christian circles, see Gillian Clark, Women in Late Antiquity: Pagan and Christian Life-styles (New York: Oxford University Press), 65. On privacy in the Roman world, see Aline Rousselle, Porneia: On Desire and the Body in Antiquity (Cambridge, Mass.: Blackwell, 1993); Peter Brown, The Body and Society: Men, Women, and Sexual Renunciation in Early Christianity (New York: Columbia University Press, 1988), esp. 315-16; Alex Scobie, "Slums, Sanitation and Mortality in the Roman World," Klio 68 (1986), 399-433, esp. 429-30; Gemma C. M. Jansen, "Social Distinctions and Issues of Privacy in the Toilets of Hadrian's Villa," JRA 16 (2003): 137-52.

65) B. Ber. 8b. While cited in the name of Rabban Gamliel, given (a) the Bavli's emphasis on modesty and (b) the fact that it is not paralleled in Palestinian sources, it is likely a Babylonian construct. On sex in a "Persian" manner (i.e., clothed) as grounds for divorce, see b. Ketub. 48a. Note that b. Ber. $8 \mathrm{~b}$ associates sex with toilet-a link made between L-O.

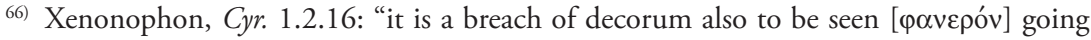
apart either to make water or for anything else of that kind," and 8.8.11: "not to eat or

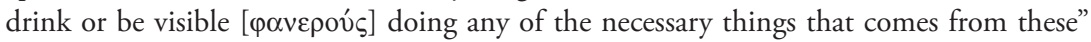
(Miller, LCL). See further Albert de Jong, Traditions of the Magi: Zoroastrianism in Greek and Latin Literature (RGRW 133; Leiden: Brill, 1997), 418-19; Herodotus, Hist. 2.35 .3 (Egyptians defecate in private); 1.133.3 (Persians urinate and vomit in private); Amanianus Marcellinus, 23.6.79 (do not urinate standing, hide to relieve themselves). De Jong argues that the Pahlavi sources do not mention that one ought not be seen easing oneself because this would have been obvious. See b. Sanh. $104 \mathrm{~b}$ (par. Lam. Rab. 1:12) on not urinating 
indicate that the Zoroastrians, like the Essenes who hid their feces from the "divine rays," considered fecal matter to be impure. ${ }^{67}$ These sources also require men to urinate while squatting, among other prohibitions against the exposure of the private parts. ${ }^{68}$ All this may partly explains the Bavli's transformation and expansion of the rules of the privy into rules of modesty.

\section{B. Ber. 62a-b: From Jerusalem to the Fields of Mahoza}

After explaining the basis of one of the three toilet rules, the Bavli continues in praise of modesty in the privy. It reports a tradition that modesty in the toilet saves one from demons, scorpions and bad dreams and continues with a story that proves this. ${ }^{69}$ The Talmud then transitions from the

in the middle of the road and Gen. Rab. 17:6 on the design of the human posterior as ensuring modesty during defecation.

67) Vendidad 17:11; Josephus, War 2:148-149; 11QT 46:15; m. Yoma 3:2 (immersion after defecation for temple priests, although see $y$. Pesah. 7:11, 35b). Cf. Manusmriti 5.138; Mark 7:19-20/Matt 15:17. b. Ber. 26a considers whether one can pray whilst facing a privy. Rava declares that one may do so if facing a Persian toilet, which hides the waste within it. In Žižek's terms toilet design expresses, "the ideological perception of how the subject should relate to excrement" (as in note 1).

68) Zoroastrian sources condemn nudity (see references in de Jong, Traditions, 419-20). For rules on urination see Pahlavi Rivayat Accompanying the Daedestan i Denig 11:3; Vendidad 18:40; Pahlavi Vendidad 18:98. On the Zoroastrian-Persian or even Islamic contexts for the Bavli, particularly with respect to urination, see David Brodsky, A Bride without a Blessing: A Study in the Redaction and Content of Massekhet Kallah and its Gemara (TSAJ 118; Tübingen: Mohr Siebeck, 2006), 365-68 and references. On the Zoroastrian-Persian context of the Bavli, see Yaakov Elman, "Talmud and Middle Persian Culture," EncJud 19:488-91 and references; idem, "World of the 'Sabboraim': Cultural Aspects of Post-Redactional Additions to the Bavli," in Rubenstein, Creation and Composition, 383-416.

69) On demonic danger in the privy, see b. Ber. 23a-b; b. Git. 70a (the demon or shed of the privy); $b$. Šabb. 67a; b. Pesah. 110a-111b; b. Ber. 51a. We see more of this concern in Babylonian materials. On this, see Isaiah Gafni, "Babylonian Rabbinic Culture," in Cultures of the Jews: A New History (ed. David Biale; New York: Schocken, 2002), 223-66. On Satan appearing to Nicetius when he was about to "answer a call of nature," see Gregory of Tours, Lives of the Fathers 17:3, trans. Edward James, Gregory of Tours: Lives of the Fathers (2d ed.; Liverpool: Liverpool University Press, 1991), 110: "And behold! There appeared to him a frightful shade, of great height, of huge size, black in colour, with an immense number of sparkling eyes, like those of a furious bull, and a large mouth that stood open as if ready to eat up the man of God. But when he made the sign of the cross against it, it vanished like ascending smoke. There is no doubt that the prince of crime had shown himself to him.” 
demonic dangers of the lavatory to concerns about the propriety of relieving oneself in the open. ${ }^{70}$ It is in this context that Rabbi Assi b. Nathan transmits a baraita to the effect that relieving oneself in an open field is permitted "as long as no one can see him [kol zman she'en havero ro' ehu]." This ruling is disputed, and then refined by Rav Ashi [BA6] who explains that what Assi. b. Nathan means by "as long as he cannot be seen by anyone" is "as long as no one can see his exposure, although he himself may be seen." While one's exposed private parts must be concealed, other parts of one's person (e.g., face) may be visible. Rav Ashi's intervention carves up the body in terms of its visibility.

Notice how the debate is no longer posed in terms of "facing" or "front or "back" or even the holy or the temple, but simply in terms of visibility, i.e., "being seen." The person relieving himself has become a (forbidden) visual object whose sight offends not the temple, but human eyes. ${ }^{72}$ Reinforcing this transformed trope, $b$. Ber. 62a continues with a series of figures of exemplary modesty, which includes the following:

[P] A funeral orator went down before Rav Nahman [BA3] and said: This man was modest in his ways [tsanu'a be-'orakhotav]. Rav Nahman said to him: Did you ever follow him into a toilet so that you would know whether he was modest or not? For it has been taught: We only call a person modest if they are modest in the toilet.

Here, in the apparent solemnity of eulogy, the Bavli poses the challenge as to whether real modesty can in fact be known, as it is hidden by its very nature-unless one is a stalking student—bringing us again to the interhuman problem of exposure and modesty (rather than the temple-human problem). The Bavli then moves to a series of Babylonian Amoraic traditions that define modesty in terms of private toilet behavior.

\footnotetext{
70) On the permissibility, or even desirability, of urinating in public (and on the dangers of withholding urine) see $b$. Ber. 44b. On the same folio Abayye also forbids a woman from urinating in front of her child (but permits it if she does so sideways).

71) PA 3, born in Babylonia. Many of the modesty related traditions and anecdotes in b. Ber. 61b-62a feature Babylonian rabbis.

72) Beginning from the determination of ve-ro'e (when he/it sees) in b. Ber. $61 \mathrm{~b}$ to this point, the Bavli makes more of the impact of vision upon modesty.
} 
After touching on a set of best practices for relieving oneself, and just before a doublet of cautionary tales about Babylonian rabbis whose privacy in the toilet is infringed, we find the following words of advice:

[Q] Abayye [BA4] said to the rabbis: When you go through the paths of Mahoza to get to the fields, do not gaze (tekhezu) to this side or to that, for perhaps $[w o] \mathrm{men}^{73}$ are sitting there, and it is not proper conduct ['orah ar'ah] to stare ('istakule) at them. ${ }^{74}$

73) Vilna, the Soncino printed edition of 1484, Oxford Opp. Add. fol. 23 (2) and Paris 671 have women [נשי] rather than men. Munich 95 and Cambridge T-S F1 (2) 109 have men [אינשי]. It does seem a little out of place to suddenly worry about women in a flow of legal and narrative that has hitherto only considered males. However, in b. Ber. $23 \mathrm{~b}$ there is explicit consideration of gender (front or rear), anatomy (solid or liquid waste matter) and consequent modesty as it pertains to differences of exposure [ giluy] during micturition and elimination. Regarding the use of human (and other) excrement for field fertilizer in Persian practice, see Pablavi Rivayat Farnbag Sros 26 (BTA, I 156, II 138), which dates itself to 1008 C.E. (see Michael Stausberg, Zoroastrian Rituals in Context [SHR 102; Leiden: Brill, 2004], 416). On excrement in Zoroastrian culture, see Mary Boyce, $A$ History of Zoroastrianism: The Early Period (Brill: Leiden, 1975), 139 and references there.

74) B. Ber. 62b (top). For a tantalizing parallel, in terms of content and to some extent in terms of literary structure, see the traditions in the ninth-century hadith collection of alBukhari 1.4.146-51 (par. Muslim Ibn Hajjaj 2:504-10). Strikingly, the hadith instruct one not to turn "his face or back toward the Qibla" but rather "face east or west." Bait-ulMaqdis (Jerusalem) is also considered. Accounts of Mohammed relate that he "answered the call of nature while sitting on two bricks Bait-ulMaqdis (Jerusalem) but there was a screen covering him" (cf. Rabbah and peeping rabbis). The question of women's exposure while going to the toilet at night in a big open space is addressed (cf. fields of Mahoza). It appears that these texts (the Bavli and these ninth-century hadith) are operating in the same discursive universe or cultural koine. For an examination of parallels between early Islamic and Talmudic purity rituals and laws (including micturation) in terms of Jewish "influence" on Islam, see Arent Jan Wensinck, "The Origin of the Laws of Ritual Purity," in The Development of Islamic Ritual (The Formation of the Classical World 26; Aldershot, England: Ashgate, 2006), 75-94. For a critique of approaches that cast Islamic law as derivative (of Jewish or Zoroastrian law), see Marion Holmes Katz, Body of Text: The Emergence of the Sunni Law of Ritual Purity (Albany, N.Y.: SUNY, 2002), esp. 5-7 and 13-15 (move away from quest for origins); Ze'ev Maghen, "First Blood," Der Islam 81 (2004): 49-95 (thanks to David Friedenreich for this reference). Katz prefers to think of Islamic ritual as having emerged as part of the "ritual koiné of the late antique and early medieval technique" which were "infused with the distinctive spiritual impulse of Islam" (8). For another nuanced argument about the relationship between Jewish and early Islamic law, which also treats purity laws (though not this specific set of laws), see Ze'ev A. Maghen, After Hardship Cometh Ease: The Jews as Backdrop for Muslim Moderation (Berlin: de Gruyer, 2006), esp. 75-77 (on urination). 
It seems that Abayye refers to looking at people relieving themselves. We can recognize the continued theme of maintaining and respecting modesty, as well as the narrative traces of the peeping rabbis who did, in fact, look (the term "proper conduct" echoes Rav's rebuke to Rav Kahana in O). The term for staring ('istakule) is often used in a gendered and sexualized context-most often, one in which men possess the gaze and turn it onto women (or in the context of prohibition thereof). ${ }^{75}$ Whether men or women are the visual objects sitting in the fields, we have an injunction or recommendation directed to the potential spectator rather than the person seen. ${ }^{76}$

In its lengthy, cautionary survey of toilet practices, rules of modesty, and even safety, the Bavli effectively moves back and forth between accounts of the human as an object and subject of the gaze. B. Ber. 61b-62b moves from temple sight, to rabbi/student sight, to exemplary figures of modest toileteers, to inter-subjective positioning and viewing. The original site/ sight of surveillance, viz. the temple, seems to have been left behind or utterly transformed into the human spectator's eye. In Foucauldian terms "we are talking about two things here: the gaze and interiorization." 77

\section{Closing the Bavli's Commentary on M. Ber. 9:5: Back to the Temple}

Persian cultural norms and rabbinic consciousness of Babylonia's geospatial distance and location vis-à-vis the temple clearly play a large part in explaining the particularities of $b$. Ber. 61b-62b. Certainly, the Babylonian authors and editors expanded the concerns of $m$. Ber. 9:5 well beyond the toilet-related concerns of the Yerushalmi. In their halakic considerations and in their narrative figurations, they have transferred and also transformed the toilet rules into a Diasporic context (this transfer itself is thematized in J-L). A set of rules that began its life as a bodily consciousness

Sincere thanks to David Friedenreich for his thoughts, references and cautions concerning these parallels.

75) See, e.g., y. Hal. 2:4, 58c; b. Ber. 24a; b. Ber. 61a. But it is also used in contexts of speculation and contemplation (e.g., about divine mysteries, m. Hag. 2:1) and idolatry (e.g., y. 'Abod. Zar. 3:1, 42b).

76) In the case of the guard, he had to be careful about not being seen by someone else. It is also just possible that the text takes for-granted that the spectator is also going to relieve himself.

77) Michel Foucault, "The Eye of Power," in Power/Knowledge: Selected Interviews and Other Writings, 1972-1977 (ed. Colin Gordon; New York: Pantheon, 1980), 149. 
of the holy of holies has been localized in Mesopotamian terms and is not just about being seen (by the putative sacred) but is also about seeing.

If, as I have argued, the intricacies of the Palestinian debate about toilet orientation vis-à-vis temple promoted a bodily hyper-sensitivity, then one might say that in the Babylonian version the Jerusalem temple has become a panopticon, internalized to produce a sense of the self as visible and as viewer, with concomitant bodily effects. An additional important feature of the Babylonian translation of these rules to inter-human concerns about modesty is the shift from the Palestinian emphasis on profane versus sacred to a preoccupation with notions of privacy. ${ }^{78}$

However despite this shift in emphasis, b. Ber. 61b-62b's commentary on $m$. Ber. 9:1 does snake its way back to the temple again, albeit via the trope of modesty. As mentioned, after Abayye's cautions against gazing at people squatting in the fields, the Talmud follows with a doublet of tales about Babylonian rabbis whose toilet privacy is trespassed. The Talmud then segues into an exemplary biblical figure of modesty: King Saul.

The biblical narrative describes Saul entering a cave, in which David and his men happen to be hiding, in order to relieve himself. David has the chance to kill Saul, but cuts off a piece of his garment to show that he could have killed him but that he refrained. The rabbinic interpretation of events is that David was moved to spare Saul because of the extreme modesty with which the latter relieved himself. ${ }^{79}$

But the modesty [tsni ut] which you have shown has caused you to be spared. What is this? As it is written: "And he came to the sheep pens [lit. fences] by the way, where there was a cave; and Saul went in le-hasekh 'et raglav [to cover his feet = eliminate] (1 Sam 24:3).” It has been taught: a fence within a fence, and a cave within a cave. R. Eleazar says: It [le-hasekh] teaches that he covered himself like a booth [sukkah].

Not only did Saul enter the cave to conceal himself but he also took precautions "within the cave" to cover himself. The Palestinian Talmud details how David "saw him lower [his garments] down a little bit, and raise [them] up a little bit."

78) In this regard we might note how much more developed hezek re'iyah is in the Bavli. See b. B. Bat. 2b-3b. See also b. Pesah. 26a on whether sight (and hearing and smell) count as meilah (trespass).

79) b. Ber. 62b, par. y. Sanh. 2:4, 20b, y. Sukkah 5:4, 55c. The Palestinian versions use more explicitly visual language. 
Until now, this is all in keeping with the thrust of the long excursus toward modesty. However, through a series of associative links, the Bavli moves from David's punishment for cutting the corner of Saul's cloak to his punishments for various other sins. In the last of these punishments (1 Chron 21), it appears that God was about to destroy Jerusalem but "saw" something that made him stay his hand. ${ }^{80}$ The Talmud asks what the object of God's sight was and offers several possibilities. These range from the patriarch Jacob, to the "ashes" of Isaac, to the atonement money, and finally, the temple. The Talmud ultimately alights on the last view, citing Gen 22:14 "the mountain where the Lord sees." 1

The midrash cited here plays on the ambiguity of the phrase "the mountain where/that the Lord sees/is seen" and draws from an exegetical tradition that figures the temple as a site of vision in which God can be seen and at which he gazes. As deployed here, the midrash plays with the links between vision and memory, as they pertain to the temple. ${ }^{82}$ Hence the very final gesture of the Talmud's commentary on m. Ber. 9:5 is toward the temple as a site of vision, memory, and divinity.

It is true that much of the commentary on $m$. Ber. 9:5 brings us far out of the range of the temple and into local Perso-Mesopotamian norms of interpersonal bodily modesty in the toilet. At the same time, the bulky excursus on toilet modesty is framed by, and tethered to the temple whose gaze is internalized and brought to mind and body. In linking $m$. Ber. 9:5 to toilet directions that take their cue from the temple, the Talmud creates regular opportunities to recall and to summon the temple into the everyday. ${ }^{83}$

80) 1 Chron 21:15 "and as he was about to destroy, God saw and relented." The emphasis on what God saw serves to underpin the link between the poetics of memory and vision in rabbinic, as well as other ancient, eyes.

81) This is presented in the name of R. Yohanan and then as one side of a dispute between R. Jacob b. Idi and R. Samuel b. Nahman, with the Bavli preferring the temple interpretation. For God seeing Isaac's blood see Mek. Pisha 7, s.v. Exod 12:13 (par. Tg. 1 Chr 21:15). See Gen. Rab. 56:10 (Theodor Albeck, 607-08); Jub. 18:13 for traditions that play with Gen 22:14 in terms of divine vision/visibility.

82) The temple was not yet built during David's reign. From the standpoint of the midrash's author, however, it is something to be recalled.

83) These opportunities form the inverse and opposite, directionally speaking, of those afforded by the prayer directions in $m$. Ber. 4:5-6 (par $t$. Ber. 3:14-16). Both, one in the realm of the sacred, the other in the realm of the prosaic, take their central reference point as the sublime/temple. 
Thus ends Bavli's commentary on m. Ber. 9:5. The journey has taken us from containing behavior and bodily deportment whilst facing the holy of holies, to the very specific recommendations for where to face while performing bodily functions, to the narratives of rabbis observing rabbis' micro-movements in the privy, to paeans to privy modesty and to those who conducted themselves accordingly, capped by the figure of Saul. Then the very last gesture of this lengthy excursus brings us back toward the temple once again, this time not from the viewpoint of the human body as it faces the holy of holies (whether within Scopus and while "seeing," or from Judea, the Galilee, or Babylonia), but rather through the eyes of God (Gen 22:14).

The entire Babylonian passage flits between these two possibilities of vision-seeing and being seen-whether in the shadow of the distant yet potentially omnipresent temple, or in terms of the visibility and vision of fellow human beings. ${ }^{84}$ It is this vision that allows the temple to travel through the sensitive eyes of the spectator who restrains his gaze as he traverses the fields of Mahoza littered as they are with men or women relieving themselves in postures unsuitable to behold. Thus, as much in the realm of the profane as in that of the sublime the temple becomes an internalized gaze that not only draws humans toward it in prayer, but that also travels and repels them from it, shaping their bodily movements as they perform their "lower" functions.

\section{Faces and Feces: The Temple in the Domain of the Sublime and the Profane}

Before discussing the broader implications of rabbinic toilet rules for rabbinic notions of the temple and for rabbinic piety, let us sketch the salient features of rabbinic toilet rules from the Tannaim to the later rabbis, spanning Palestine and Babylonia. Tannaitic toilet directions are addressed directly in t. Meg. 3:26 and demonstrate the same geospatial concern to direct the body along temple co-ordinates as in $m$. Ber. 9:5, m. Sukkah 5:5, m. Ber. 4:5-6 and t. Ber. 3:14-16. At this point, the explicit and particular concern of the toilet rules in $t$. Meg. 3:26 is that waste matter is not aimed

84) Or even, as implied, over the course of b. Ber. 61b-62a, the harmful spirits that lurked in Mesopotamian privies. 
toward the Jerusalem temple..$^{85}$ Unlike the Essenes, the rabbis did not find excretia to be impure and hence did not focus on it. They were not interested in developing the Deuteronomic injunctions in Deut 23:12-15 beyond their most obvious war-camp setting (in t. Meg. 3:25).

Comparing Qumran and Tannaitic toilet rules, one might say that the former, in focusing on disposal, expel the body and its products, leading to more of a binary arrangement of space (inside/outside; sacred/profane) and a more static relation to the sacred center. The central node in the rabbinic map does not expel the body (or its products) but rather has a dynamic relation to it, giving the central node an extensive, satellite-like reach. Not only does the sacred countenance the profane in its proximity (if properly directed) thereby incorporating it, but in addition, the body also incorporates the temple (though its practices). Thus, a relational, farreaching map is drawn which goes beyond the spatial and temporal proximity of the temple itself. Rabbinic toilet rules, in other words, draw a far more expansive map than those of Qumran. The geopolitical and temporal conditions in which both sets of rules were drawn go some way toward explaining these different emphases. ${ }^{86}$ In both sets of rules there is a resistance to a dominant geospatiality, whether that drawn by the Jerusalem priesthood or Roman imperium.

The later rabbinic sources marry the specificities of $t$. Meg. 3:26 to the wider concerns of t. Meg. 3:21-25, m. Ber. 9:5, m. Sukkah 5:5, m. Ber. 4:5-6, and $t$. Ber. 3:14-16, to elaborate the ways by which the body is not exposed in the direction of the temple. ${ }^{87}$ Here too, the strategy is incorporation of temple presence through bodily direction rather than exclusion and disposal (as per Deut 23:12-15 and the Qumran rules). The potential

85) This concern is not evident in the Qumran sources. On the contrary, prayer orientation mandates turning the back upon the Jerusalem temple. That the orientation of rear or genitalia toward the temple is not a worry is clear from the language in $t$. Meg 3:26 (E), which talks of the "back" and the "front" being toward the "holy."

86) For example, Qumran sources locate the sacred within their own confines and in competition with the Jerusalem center. Tannaitic sources are produced in a post-temple world, even as they then go on to produce an (often) ahistorical, unceasing, Jerusalem temple.

87) To this extent, one might Deut 23:15, with its description of God walking about the "holy" camp and its desire that he "should not see [yir'e] in you anything of 'ervat davar" is the inspiration. 'ervat davar is a difficult construct. It is used (with "eyes") in Deut 24:1, but more generally 'ervah means genital nakedness. In Deut 23:15 it seems to refer to the prohibition against genital nakedness in the holy camp (which evacuating would entail), and this seems to be the sense understood by the later rabbis, especially in the Bavli with its emphasis on vision. 
of this incorporation to be transferable beyond the proximate and temporal confines of the sacred, across Palestine and ultimately even beyond its borders, is fully realized in different ways by the Yerushalmi and the Bavli.

The Palestinian Talmud poses its set of toilet directions in terms of posttemple temporality - suggesting through the voice of R. Judah that perhaps the directions do not apply when the temple is no longer up and running. It also suggests (along with $t$. Meg 3:26) that the spatial reach of the rules might be limited to the outer edges of the city. However, while the Yerushalmi signals awareness of temporal and spatial limits, its anecdotes suggest that such spatio-temporal limitations are not to be taken up. The Bavli quite explicitly poses its toilet directions in the face of both temporal and geospatial constraints, squarely raising the issue of the posttemple temporality and distinguishing between the "land of Israel" and "outside of the land," and even dividing Palestine up regionally (between Judea and the Galilee). ${ }^{88}$

In different ways, both the Yerushalmi and the Bavli suggest that the temple draws and diverts humans to and from itself, and exerts widereaching force in shaping humans' bodily movements and orientations. In both Palestine and Babylonia the temple forms a pivot, a sacred cardinal point, that determined the choreography of bathroom functions as much as those of sublime supplications. In its more interiorized form in Babylonia, the temple also could become a kind of portable panopticon that governed inter-human modesty and privacy ${ }^{89}$ In Palestine, through shifts in the material landscape, the temple's apparently uninterrupted centrality shaped rabbinic bodies and allowed its continuity to be upheld by those very bodies in turn. ${ }^{90}$

\footnotetext{
88) For an analysis of the intra Babylonian-Palestinian rabbinic politics of geospatial mapping in terms of the ways rabbis drew up the boundaries of Israel and Babylonia, see Isaiah Gafni, Land, Center and Diaspora: Jewish Constructs in Late Antiquity (Sheffield: Sheffield Academic Press, 1997).

89) This is not to say that both Qumran and Palestinian rabbinic laws do not worry about bodily exposure in general. However I do not see explicit concern with privacy (pace Magness, Stone and Dung, 130-44) as in the Babylonian rabbinic materials.

90) The enormous literature in cultural history and cultural geography on the spatial imagination, landscape, mapping, imperialism, colonialism and resistance offers excellent analytical possibilities for thinking through the generation of such maps. Just two examples include C. W. J. Withers, "Place and the 'Spatial Turn' in Geography and in History," JHI 70 (2009): 637-58 and Derek Gregory, "Connective Dissonance: Imaginative Geographies and the Colonial Present," in Space Odysseys: Spatiality and Social Relations in the 21st Century (ed. Jørgen Ole Bærenholdt, Kirsten Simonsen; Aldershot: Ashgate, 2004), 197-214
} 


\section{Toilet, Temple and Rabbinic Piety}

Let us recall Žižek's observation that we cannot account for cultural variation among toilet habits by utilitarian considerations alone, but that we must rather look to deeper ideologies. Žižek's own formulation is, of course, culturally specific, as he focuses on how the subject relates to excretia. One of the important features of rabbinic toilet rules is that they tend more to the body itself than to its products, and not just to the body, but to the body in space, in other words, to the body in relation to the sacred. ${ }^{91}$ There is nothing obvious, or inevitable about these features of rabbinic toilet practices. These practices actively inserted the temple's coordinates as those from which the body-wherever it was-took direction. The key effect of the temple being inscribed onto bodily practices of toilet was to produce a new kind of geospatial map.

We might consider toilet practices along with other rabbinic ways of inscribing the temple. A variety of later rabbinic practices (ostensibly or ostentatiously) took their cues from the temple. These included foodways, liturgical content, synagogue sacrality, festival ritual, mourning practices and the enormous body of thinking through and about the temple instantiated in the rabbinic scholastic, halakic and narrative project. ${ }^{92}$ It is fair to

and bibliographies in both. One might think of the map produced by the bodily practices of the rabbis as a counter to the kinds of mapping that imperial mapping produced: each constituted a space that disregarded existing topographies in different ways (whether imaginary and ritual and/or concrete and violent). For an insightful analysis of rabbinic sources that deploys such notions see Ra'anan Boustan, "The Dislocation of the Temple Vessels: Mobile Sanctity and Rabbinic Rhetorics of Space," in Jewish Studies at the Crossroads of Anthropology and History: Authority, Diaspora, Tradition (ed. Ra anan S. Boustan, Oren Kosansky, and Marina Rustow; Philadelphia: University of Pennsylvania Press, 2011), 135-46, nn. 365-70 and idem, "The Spoils of the Jerusalem Temple at Rome and Constantinople," in Antiquity in Antiquity: Jewish and Christian Pasts in the Greco-Roman World (ed. Gregg Gardner and Kevin Osterloh; Tübingen: Mohr-Siebeck, 2008), 327-72.

91) The sensory perception of excretia is a concern when it is proximate to the person reciting the shema. See above n. 62.

92) On temple-sacrificial cult as an important frame through which the form, content and conceptualizations of prayer were formed, see Reuven Kimmelman, "Rabbinic Prayer in Late Antiquity," in The Cambridge History of Judaism, The Late Roman-Rabbinic Period (Cambridge: Cambridge University Press, 2006), 573-611. On the "templization of the synagogue" see Steven Fine, This Holy Place: On the Sanctity of the Synagogue During the Greco-Roman Period (Notre Dame, Ind.: University of Notre Dame Press, 1997) and Robert Goldenberg, "The Destruction of the Temple, Its Meaning and Its Consequences," in The Cambridge History of Judaism, The Late Roman-Rabbinic Period, 191-205. See note 27 above for temple mourning and pilgrimage practices. Three pilgrimage festivals, Sukkot, 
say that the work of mapping performed by the standing (or squatting) body was functionally and effectively different to other temple-related practices that invoked, memorialized, or were supposedly modeled on temple institutions or rituals.

I have argued here that the map produced and the bodily techniques deployed by toilet practices were complementary to those of prayer practices. This prosaic (and sublime) labor effected a map whose topography was drawn along political, geographical and pietistic planes. The fact that the temple was destroyed in 70 C.E. was not without significance for the topography of this map, but neither should the temple's centrality be taken as obvious. The sense of naturalness and obviousness by which the temple assumes centrality is itself the product of rabbinic work. Hence the creativity and inventiveness with which later rabbinic practices often obscured their own inventedness extends also to rabbinic appropriations and reconstructions of the temple. What Robert Goldenberg refers to as the rabbinic success in "building a Jewish way of life that made the temple unnecessary in practice while it remained indispensable in theory" ought not naturalize the concerted exegetical, halakic, narrative, mythic and ritual labor necessary to maintain the appearance of both the temple's ongoing centrality and lamentable absence. ${ }^{93}$

Thus, the later rabbinic bodily (and mental) focus on the temple as the destination and direction for the standing prayer was not an inevitable move, neither was the concomitant development of toilet directions. Both need to be understood as a part of a set of practices designed to build a post-temple temple. ${ }^{94}$ The effect of the collaboration and mutual

Passover, Shavuot which were agricultural and cultic in focus were both remembered and transformed by the rabbis in different ways. For a study of how sukkot survived or was reinvented after the temple, see Jeffrey L. Rubenstein, The History of Sukkot in the Second Temple and Rabbinic Periods (Atlanta: SBL, 1995). Perhaps the most remarkable instance of temple-related practice was the rabbinic memory and lawmaking concerning a panoply of temple-related matters (see Goldenberg, "Destruction," 200-202). I would suggest that there is a categorical and functional difference between practices (ritual, institutional, spatial) that explicitly address or lament the pastness of the temple and those that invoke its presence (sometimes ignoring its actual absence).

93) Robert Goldenberg, "Destruction," 202.

94) Only later synagogues were oriented toward the temple. Note also, that in some locations praying toward the temple meant turning the back/rear upon the east (an insult to Christian and Zoroastrian prayer orientations). For two important analyses of the dynamics of Christian imperial spatial imaginary concerning late antique Palestine, see Andrew Jacobs, Remains of the Jews: The Holy Land and Christian Empire in Late Antiquity (Stanford: 
constitution of bodies (in toilet and prayer) and temple was of a map that could transcend spatial, material, and temporal boundaries, limitations and reconfigurations. Whether languishing in ruins, overtaken by a temple to Jupiter, lamented by Jewish pilgrims, or reshaped into a Christian center, the rabbinic temple could, when effected by bodily practices of toilet and prayer, remain standing. Thus, even the most profoundly prosaic of practices could refuse contemporaneous, sometimes successive and sometimes overlapping, geopolitical maps of Rome, Christendom and Persia.

In Palestine and in Babylonia, the body and its parts (faces, hearts, eyes, rears), whether in prayer or toilet, together with the temple-even, or perhaps especially, as it no longer stood-became a way to traverse gaps and fissures in time and space, absence and presence, and in Babylonia a way to figure the boundaries of modesty and privacy. The body, even at its most prosaic moments, was endowed with the potential to productively invoke and create the sacred, and ultimately to form the rabbinic subject in space.

Stanford University Press, 2004) and Oded Irshai, "The Christian Appropriation of Jerusalem in the Fourth Century: The Case of the Bordeaux Pilgrim," JQR 99 (2009): 465-86. 